\title{
EVALUASI PELAKSANAAN KERJASAMA ANTAR PEMERINTAH PROVINSI DKI JAKARTA DENGAN PEMERINTAH PROVINSI JAWA TENGAH DALAM PENANGANAN PENYANDANG MASALAH KESEJAHTERAAN SOSIAL (PMKS)
}

\author{
Embun Sari Tambunan \\ embunsaritambunan@gmail.com \\ Witarsa Tambunan \\ witarsa.oke@gmail.com
}

\begin{abstract}
Abstrak
Tujuan penelitian ini untuk menjelaskan bagaimana pelaksanaan dan permasalahan-permasalahan yang timbul akibat pelaksanaan Kerjasama Antara Pemprov DKI Jakarta dengan Pemprov Jawa Tengah; Dan juga untuk mengidentifikasi sejauh mana Visi dapat dijadikan pedoman/arah dengan pelaksanaan kerjasama antar daerah; Membandingkan dan menganalisis sejauhmana sub Variable Visi, Program, Anggaran dan Pengawasan berpengaruh / berhubungan dalam pelaksanaan kerjasama antar daerah; Juga untuk menjelaskan sejauh mana hasil evaluasi pelaksanaan kerjasama Pemprov DKI Jakarta Pemprov Jateng dalam penanganan PMKS dapat direkomendasikan kepada kedua Pemda.

Berdasarkan analisis yang telah dilakukan pada bagian - bagian diatas, telah terjawab bahwa Visi kerjasama antar daerah sebagai arah/pedoman untuk melaksanakan penaganan PMKS, Konsistensi daerah dan dukungan terhadap anggaran penanganan PMKS melalui kerjasama antar daerah dan Pengawasan terhadap pelaksanaan program penanganan PMKS telah dilakukan melalui kerjasama antar daerah.
\end{abstract}

Kata Kunci: Kerjasama Antar Daerah, Penyandang Masalah Kesejahteraan Sosial (PMKS) 


\begin{abstract}
The purpose of this study is to explain how the implementation and problems arising from the implementation of the cooperation between the DKI Jakarta Provincial Government and the Central Java Provincial Government; And also to identify the extent to which the Vision can be used as a guideline/direction by implementing Inter-Regional Cooperation; Comparing and analyzing the extent to which the sub-variables of Vision, Program, Budget and Supervision affect / relate to the Inter-Regional Cooperation ; Also to explain the extent of evaluation result of implementation of coorperation between the DKI Jakarta Provincial Government and Central Java Provincial Government in handling PMKS can be recommended to both local governments

Based on the analysis that has been carried out in the sections above, it has been answered that the vision of inter-regional cooperation is the direction / guideline for the management of PMKS. Regional consistency and support for handling PMKS's budget through Inter-Regional Cooperation and Supervision of the implementation of the PMKS handling program has been done through Inter- Regional Cooperation
\end{abstract}

Keywords: Inter-Regional Cooperation, People with Problems Social Welfare (PMKS) 


\section{A. PENDAhUluan}

Jakarta sebagai lbukota Negara RI memperoleh kedudukan yang setingkat dengan Propinsi lainnya di Indonesia. Namun karakteristik wilayahnya sangat berbeda dengan Provinsi lainnya, sebab Jakarta merupakan propinsi berciri perkotaan dan berkedudukan sebagai ibukota negara. Dengan demikian permasalahan yang dihadapi adalah lebih kompleks dan bersifat multi dimensional. Luas wilayah Kota Jakarta $\pm 652 \mathrm{Km}^{2}$ dengan jumlah penduduk \pm 11 juta jiwa dengan strata sosial yang beraneka ragam serta terdiri atas berbagai etnis, membuat Kota Jakarta ibarat sebuah cawan pembauran (Melting Pot) dengan berbagai implikasinya.

Kota Jakarta memiliki daya tarik yang kuat bagi dunia usaha, dan investasi baik di sektor industri, perdagangan besar dan retail serta usaha jasa. Berdasarkan data Badan Koordinasi Penanaman Modal Daerah Provinsi DKI Jakarta, pertumbuhan investasi domestik dalam bentuk jumlah proyek meningkat dari tahun ke tahun . Hal ini memperlihatkan besarnya potensi kota Jakarta untuk investasi dan pengembangan dunia usaha. terutama di sektor jasa yang mampu menyerap tenaga kerja dalam jumlah yang besar 440.578 TKI. Pertumbuhan ekonomi dan dunia usaha yang positif tersebut juga dapat dilihat melalui Pendapatan Asli Daerah (PAD), yang meningkat secara signifikan mendukung pelaksanaan pembangunan DKI Jakarta. Hal tersebut dapat dilihat pada tahun anggaran 1991 /1992 Provinsi DKI Jakarta mempunyai PAD hanya sebesar Rp 1,3 trilyun dan pada tahun anggaran 1999/2000 PAD DKI Jakarta meningkat menjadi Rp 3,7 trilyun Kenaikan PAD yang cukup besar ini merupakan peluang dan sekaligus merupakan tantangan bagi Pemda DKI Jakarta untuk lebih giat menggali potensi Daerah.

Karakteristik Jakarta yang demikian memiliki daya tarik yang kuat bagi penduduk dari berbagai daerah untuk bermigrasi ke Jakarta . Penduduk yang paling tinggi berurbanisasi ke Jakarta adalah penduduk asal Daerah Jawa Barat merupakan urutan pertama diikuti Daerah Jawa Tengah dan Yogyakarta diurutan kedua serta Jawa Timur diurutan ketiga.

Dari uraian tersebut dapat dilihat betapa Kota Jakarta telah menimbulkan Full Factor "daya tarik", artinya Jakarta merupakan kota yang menjanjikan, sehingga menciptakan daya tarik bagi penduduk untuk datang ke lbukota. Disamping itu Kota Jakarta menampung penduduk pendatang akibat "daya dorong" (push factor) kemiskinan Desa/Daerah. Oleh karena itu, masyarakat desa/daerah lain datang ke Jakarta mempunyai tujuan ingin merubah nasib, memperbaiki taraf kehidupan dan mempertahankan hidup. Kedua indikator tersebut, merupakan pemicu (trigger off) masyarakat berurbanisasi ke Jakarta.

Urbanisasi tersebut mengakibatkan adanya kompetisi dan pertarungan hidup yang keras yang pada gilirannya menimbulkan masyarakat yang berkualitas akan masuk dan menguasai sektor formal seperti : mendapat pekerjaan, berdagang/berusaha dan lain-lain, dan masyarakat yang kurang berkualitas ini hanya dapat berusaha dalam sektor informal seperti : tukang becak, ojek, pedagang kaki lima. Sementara itu sebagian masyarakat yang dikarenakan berbagai faktor, baik faktor dari dalam dirinya maupun faktor dari luar, kehilangan kemampuan untuk berinteraksi dengan lingkungannya yang disebut 
tuna kualitas. Masyarakat seperti ini akan menjadi residu sosial, karena tidak mampu bersaing dalam pertarungan hidup, kemudian mereka gagal, terhempas dan terdampar menjadi masyarakat Penyandang Masalah Kesejahteraan Sosial (PMKS) seperti : anak terlantar, anak jalanan, anak nakal, bekas korban narkotika, bekas narapidana, gelandangan, pengemis, wanita tuna susila, lanjut usia terlantar, penyandang cacat dan waria.

Implikasi dari banyaknya PMKS ke Jakarta berkecenderungan menimbulkan berbagai kesenjangan sosial, seperti : lingkungan buruk; ruang terbuka kurang; kebutuhan primer; dan kebutuhan sekunder meningkat; perilaku warga kota yang semakin individualis; masalah kesejahteraan sosial (PMKS); masalah ketenagakerjaan; masalah kebersihan/kesehatan; dan masalah populasi penduduk akibat dari urbanisasi .

Urbanisasi PMKS ke Jakarta jumlahnya tiap tahun mengalami kecenderungan menurun, tapi pada saat krisis moneter melanda Indonesia (1998) angka urbanisasi tersebut cenderung menurun karena sulitnya lapangan kerja dan banyaknya orang di PHK di Jakarta, akan tetapi pada tahun 1999 angka urbanisasi tersebut meningkat. Arus urbanisasi ke Jakarta tersebut didorong oleh faktor ekonomi yang sulit di desa bila dibandingkan dengan hidup di Kota Jakarta, sehingga adanya anggapan masyarakat desa bahwa menjadi PMKS di DKI Jakarta apapun kondisinya masih jauh lebih baik dari pada tinggal di desa, disisi lain kondisi kehidupan di pedesaan tidak secerah harapan dimana lapangan kerja terbatas, dan upah kerja lebih kecil bila dibandingkan dengan Kata Jakarta, sehingga menjadi PMKS dianggap sebagai solusi dari himpitan kesulitan hidup.

Dalam rangka penanganan PMKS tersebut Pemprov DKI Jakarta memberikan pelayanan kepada PMKS, baik melalui sistem panti sosial dan diluar panti sosial. Pelayanan yang diberikan berbentuk pembinaan sosial, pembinaan mental, pelatihan ketrampilan, bantuan stimulasi dalam rangka kemandirian.

Setelah pembinaan diberikan kepada Penyandang Masalah Kesejahteraan Sosial (PMKS) dan sudah dianggap selesai, langkah selanjutnya adalah kegiatan penyaluran . Kegiatan penyaluran meliputi usaha mandiri, kembali pada keluarga dan pemulangan ke Daerah asal. Adapun Daerah asal urbanisasi adalah Jawa Barat, Jawa Tengah , DI Yogyakarta, Jawa Timur dan luar Jawa, lihat pada tabel 2. Usaha Pemprov DKI Jakarta untuk memulangkan Penyandang Masalah Kesejahteraan Sosial ke Daerah asal dibutuhkan Kerjasama Antar Daerah. Kerjasama antar Daerah merupakan salah satu kebijakan Gubernur DKI Jakarta dalam mengatasi masalah PMKS di DKI Jakarta, sebab pengalaman menunjukkan bahwa pemulangan Penyandang Masalah Kesejahteraan Sosial ke Daerah asal tanpa melibatkan Pemda setempat penanganannya kurang berhasil atau tidak efektif.

satu daerah Salah yang paling besar penduduknya berurbanisasi ke Jakarta adalah Daerah Provinsi Jawa Tengah . Itulah sebabnya dalam penanganan masalah Sosial di DKI Jakarta dilakukan kerjasama dengan Pemerintah Provinsi Jawa Tengah.

Kerjasama Pemprov DKI Jakarta dengan Pemprov Jawa Tengah di bidang kesejahteraan sosial, terutama dalam penanganan Penyandang Masalah 
Kesejahteraan Sosial (PMKS) sejak 14 April 2000 diwujudkan dalam tiga aspek. Pertama dalam bentuk pertukaran informasi tentang masalah sosial yang dijadikan sebagai bahan pembanding, dalam merumuskan program kerja. Kedua, berupa bantuan pemulangan pengiriman Penyandang Masalah Kesejahteraan Sosial ke Jawa Tengah. Ketiga, dalam bentuk pelatihan ketrampilan dan pertanian terpadu yang disiapkan untuk bertransmigrasi. Pelatihan ini dilaksanakan di Panti Karya Samekto Karti Comal Pemalang Jawa Tengah. Kendatipun ketiga aspek tersebut telah dilaksanakan secara intensif, namun manfaat kerjasama Jakarta dengan Jawa Tengah dalam Penanggulangan Masalah Sosial dinilai kurang berhasil dalam meningkatkan disiplin sosial masyarakat Jakarta pada umumnya khususnya masyarakat pendatang, artinya Kota Jakarta masih terlihat tidak tertib dan semakin semrawut sehingga secara tidak langsung masalah PMKS merupakan hambatan dan tantangan pembangunan Jakarta.

Agar mampu menanggulangi hambatan dan tantangan pembangunan tersebut, maka setiap Pemda dituntut untuk mampu meningkatkan kapasitas dan kapabilitasnya (capacity and capability improvements) . "Peningkatan kapasitas" berkaitan erat dengan kemampuan Pemda menyerap atau melaksanakan fungsi -fungsi, tugas dan tanggung jawab yang telah diberikan kepadanya (given). Hal ini berkaitan dengan "Inward Character" atau hakekat Pemerintah Daerah dalam hubungannya dengan tanggung jawab yang telah dimandatkan (Logodef, 1993 : 2). Untuk mengatasi masalah pembangunan yang cukup pelik (termasuk masalah PMKS) tersebut, tiap-tiap Daerah harus berupaya mengoptimalkan sumber daya yang dimiliki dengan meningkatkan kapabilitas (capacity building). Peningkatan kapabilitas Pemda meliputi peningkatan pengaturan dan peningkatan pelayanan (termasuk dalam penanganan PMKS), antara lain melalui program kerjasama antar Daerah.

Kerjasama antar Daerah, adalah satu fenomena yang dilandasi oleh dua prinsip, yaitu prinsip solidaritas yang didukung oleh perasaan senasib sepenanggungan serta sifat altruisme atau tidak memikirkan diri sendiri, mau berkorban untuk orang lain, dan prinsip kedua yaitu sinerji, bahwa dengan sikap saling membantu dan melengkapi, sesama Pemda akan mampu meningkatkan kapabilitas Daerahnya masing-masing. Kemudian lebih jauh, kerjasama tersebut tetap menghargai kekhususan masing-masing Daerah, dengan demikian dapat memperkokoh persatuan dan kesatuan bangsa, saling memberi manfaat, baik secara langsung maupun tidak langsung, dan kerjasama antar Daerah pada gilirannya harus dapat mendorong kemandirian masing-masing Daerah menuju penyelenggaraan otonomi Daerah yang luas, nyata dan bertanggung jawab. Terlebih -lebih dengan diberlakukannya UU Nomor 22 Tahun 1999 tentang Pemerintahan Daerah menggantikan UU Nomor 5 Tahun 1974 sangat jelas besarnya kewenangan Daerah dalam seluruh bidang Pemerintahan (pasal 7) dan kewenangan mengelola sumberdaya nasional yang tersedia di wilayahnya, memelihara kelestarian lingkungan sesuai dengan peraturan perundangundangan (pasal 10). Hal ini memerlukan peningkatan kapabilitas Pemerintah Daerah melalui kerjasama antar Daerah untuk mengambil manfaat seluas-luasnya peluang yang diberikan kepada Daerah. Dengan berbagai kelebihan dan 
kekurangan dari kondisi tersebut, namun kota Jakarta mendorong Pemprov DKI Jakarta untuk mensinerjikkan potensinya dengan Daerah-daerah lain di Indonesia melalui jalinan kerjasama antar Daerah sebagaimana diamanatkan oleh Pasal 65 ayat (1) UndangUndang Nomor 5 Tahun 1974 tentang Pokok-Pokok Pemerintahan Di Daerah menyatakan : "Beberapa Pemerintah Daerah dapat menetapkan Peraturan Bersama untuk mengatur kepentingan Daerahnya secara bersama-sama". Dan juga Pasal 87 ayat (1) Undang-Undang Nomor 22 Tahun 1999 tentang kapabilitas Daerahnya masing-masing. Kemudian lebih jauh, kerjasama tersebut tetap menghargai kekhususan masing-masing Daerah, dengan demikian dapat memperkokoh persatuan dan kesatuan bangsa, saling memberi manfaat, baik secara langsung maupun tidak langsung, dan kerjasama antar Daerah pada gilirannya harus dapat mendorong kemandirian masing-masing Daerah menuju penyelenggaraan otonomi Daerah yang luas, nyata dan bertanggung jawab. Terlebih-lebih dengan diberlakukannya UU Nomor 22 Tahun 1999 tentang Pemerintahan Daerah menggantikan UU Nomor 5 Tahun 1974 sangat jelas besarnya kewenangan Daerah dalam seluruh bidang Pemerintahan (pasal 7) dan kewenangan mengelola sumberdaya nasional yang tersedia di wilayahnya, memelihara kelestarian lingkungan sesuai dengan peraturan perundang-undangan (pasal 10). Hal ini memerlukan peningkatan kapabilitas Pemerintah Daerah melalui kerjasama antar Daerah untuk mengambil manfaat seluas-luasnya peluang yang diberikan kepada Daerah.

Dengan berbagai kelebihan dan kekurangan dari kondisi tersebut, namun kota Jakarta mendorong Pemprov DKI Jakarta untuk mensinerjikkan potensinya dengan Daerah-daerah lain di Indonesia melalui jalinan kerjasama antar Daerah sebagaimana diamanatkan oleh Pasal 65 ayat (1) UndangUndang Nomor 5 Tahun 1974 tentang Pokok-Pokok Pemerintahan Di Daerah menyatakan : "Beberapa Pemerintah Daerah dapat menetapkan Peraturan Bersama untuk mengatur kepentingan Daerahnya secara bersama-sama". Dan juga Pasal 87 ayat (1) Undang-Undang Nomor 22 Tahun 1999 tentang Pemerintahan Daerah menyebutkan : "Beberapa Daerah dapat mengadakan kerjasama antar Daerah yang diatur dengan Keputusan Bersama".

Dari kedua Undang-Undang tersebut dalam perkembangan lebih lanjut, kerjasama DKI Jakarta dengan Daerah lain semakin meluas, tidak hanya antara dua Daerah (Dwipraja) saja, tapi berkembang menjadi kerjasama tiga Daerah (Tripraja) dan akhirnya kerjasama terjalin dengan lima Daerah Propinsi se Jawa dan Bali dalam wadah SAD PRAJA UTAMA (enam Pemerintah Daerah Propinsi) . Berbagai bentuk hubungan kerjasama tersebut tidak semata-mata dimaksudkan sebagai wadah interaksi antar instansi/perangkat Pemerintah Daerah melainkan juga menjadi wahana kerjasama antara para pengusaha dalam wujud perdagangan dan investasi. Juga kerjasama antar LSM dalam bentuk paguyuban Daerah asal. Hubungan dan kerjasama yang semula dikenal dengan program government to government ( $\mathrm{G}$ to $\mathrm{G}$ ) telah berkembang menjadi kerjasama Pemerintah dengan para Pengusaha maupun dengan LSM (Private and Public Partnership Cooperation) antar Daerah. 
Dari uraian di atas dan pengalaman dalam melaksanakan kerjasama antar Daerah, peran Visi sangat menentukan, sebab pelaksanaan kerjasama antar Daerah harus bisa memproyeksikan tentang sasaran dan harapan yang akan dicapai oleh Pemda yang melakukan kerjasama antar Daerah, atau dengan pengertian lain Visi itu harus dapat menjawab tantangan atau masalah yang dihadapi oleh Pemda yang melakukan kerjasama antar Daerah .

Adapun Visi kerjasama antar Daerah DKI Jakarta adalah menyelesaikan masalah antar Daerah secara bersama yang saling menguntungkan, sedangkan Misinya adalah :

1. Mensinerjikan Kerjasama Antar Daerah dengan pembangunan Daerah

2. Meningkatkan kesadaran Daerah sebagai NegaraKesatuan

3. Mencegah disintegrasi bangsa

Di atas telah disebutkan bahwa Pemerintah Propinsi DKI Jakarta dalam pelaksanaan Kerjasama Antar Oaerah mempunyai Visi dan Misi, namun dalam kenyataannya Visi tersebut belum bisa menjawab tantangan/masalah kerjasama Pemprov DKI Jakarta dengan Pemprov Jawa Tengah dalam penanggulangan PMKS, artinya Visi tersebut belum bisa menyelesaikan penanggulangan PMKS. Sehingga timbul pertanyaan apakah perumusan Visi tersebut yang tidak jelas ataukah substansi masalahnya (hal yang dikerjasamakan) yang begitu luas/kompleks ?

Demikian juga dalam hal program, berdasarkan prosedur yang baku sebelum program Kerjasama Antar Daerah ditanda tangani oleh Gubernur, didahului oleh pembicaraan/pembahasan antar staf untuk membahas program apa yang akan dilaksanakan, artinya usulan program itu merupakan kebutuhan (need) yang datangnya dari masyarakat (bottom-up) dan disampaikan kepada pejabat Pemda, selanjutnya usulan tersebut oleh pejabat instansi terkait dilakukan kajian yang bersifat studi kelayakan, hasil kajian itulah yang disampaikan kepada Gubernur untuk dijadikan program kerjasama antar Daerah ini yang disebut model "Buttom-up Planning". Disamping itu ada model "Top Down Planning" yakni usulan program yang sifatnya "dadakan" atau keinginan (directions) yang datang dari pejabat atasan atau instansi yang lebih tinggi (Departemen) untuk dilaksanakan oleh Pemerintah Daerah. Oleh Gubernur program tersebut dimasukkan dalam program kerjasama antar Daerah.

Kerjasama antar Daerah Pemprov DKI Jakarta dengan Pemprov Daerah lain programnya ada yang inisiatif usulannya datang dari Pemerintah $(\mathrm{P})$ dan ada yang dari Masyarakat (S). Demikian juga program tersebut ada yang direalisasikan dan ada yang tidak dialokasikan dalam APBD Daerah, khusus program di bidang sosial kerjasama Pemprov DKI Jakarta - Pemprov Jawa Tengah terlihat bahwa inisiatif usulan datangnya baik dari Pemerintah dan masyarakat, demikian juga dengan realisasi program untuk kegiatan penanggulangan PMKS mendapat alokasi anggaran pada APBD Propinsi DKI Jakarta. Kegiatan penanggulangan PMKS tersebut diharapkan dapat menjawab masalah yang dihadapi kedua Daerah. Namun, dalam kenyataannya program Kerjasama Antar Daerah tersebut tidak dapat menjawab masalah yang dihadapi secara maksimal. Oleh karena itu, timbul pertanyaan apakah perumusan program 
tersebut tidak dimulai dengan studi kelayakan ? atau program tersebut disusun hanya berdasarkan keinginan (want) dan bukan merupakan suatu kebutuhan (need) bagi kedua Daerah, ataukah program tersebut tidak konsisten dipatuhi oleh kedua Daerah. Pelaksanaan program Kerjasama DKI Jakarta dengan Daerah lain didukung oleh APBD DKI Jakarta, baik dalam Anggaran Rutin maupun Pembangunan (Proyek) Anggaran Pembangunan yang berbentuk proyek ini dialokasikan dalam APBD untuk mendukung program yang telah disepakati oleh Pemerintah Propinsi DKI Jakarta dengan Daerah lain. Adanya Anggaran tersebut dalam APBD terlebih dahulu melalui pembahasan yang bertahap/bertingkat yaitu mulai dari internal Unit/Dinas sampai dengan DPRD. Biasanya Anggaran Pembangunan ini dituangkan dalam Peraturan Daerah tentang APBD.

Mengingat bahwa beberapa kegiatan kerjasama yang dilaksanakan juga memiliki aspek non teknis (administratif) berupa kunjungan perundingan (negosiasi) penyusunan program, pembinaan dan evaluasi, maka kerjasama juga memerlukan dukungan anggaran rutin.

Program kerjasama antar Daerah DKI Jakarta dengan Daerah lain mendapat alokasi anggaran pada APBD DKI Jakarta, dan anggaran tersebut menunjukkan peningkatan dari tahun ke tahun. Pengalokasian anggaran tersebut serta adanya peningkatan anggaran mempunyai hubungan dengan kondisi kerjasama DKI dengan Daerah Propinsi lain, artinya kerjasama antar Daerah tersebut berjalan dengan baik (aktif), pasif, dan tidak aktif.

Dari uraian tersebut terlihat bahwa kerjasama Pemprov DKI Jakarta dengan Daerah lain mendapat dukungan anggaran atau dengan pengertian lain dialokasikan pada APBD DKI Jakarta. Namun, dalam kenyataannya pelaksanaan kerjasama Pemprov DKI Jakarta dengan Pemprov Jawa Tengah dalam penanganan PMKS belum optimal. Itulah sebabnya timbul pertanyaan apakah realisasi anggaran pembangunan maupun rutin tersebut sekedar realisasi saja dari APBD dengan tidak mempertimbangkan jumlah anggaran yang telah disepakati untuk melaksanakan program penanggulangan PMKS, atau Pemerintah Propinsi yang tidak konsisten untuk memberikan dukungan anggaran terhadap kesepakatan program kerjasama dimaksud.

Disamping faktor Visi SDM yang melaksanakan kerjasama antar Daerah, pengalaman menunjukkan bahwa faktor pengawasan turut menentukan berhasil tidaknya pelaksanaan program kerjasama antar Daerah itu, sebab melalui pengawasan diharapkan kegiatan-kegaiatan program kerjasama antar Daerah harus sesuai dengan rencana yang telah ditentukan sebelumnya. Perencanaan itu menyangkut hak dan kewajiban dari Daerah yang melakukan kerjasama antar Daerah. Untuk itulah pelaksanaan program kerjasama perlu diawasi dan dimonitor secara berkala dan terus menerus yang akan dijadikan bahan evaluasi. Namun, dalam realisasinya faktor pengawasan ini sulit untuk dilaksanakan, sebab tidak jelasnya unit mana yang melakukan pengawasan dan Daerah mana yang melakukan pengawasan terhadap program kerjasama yang bersifat fisik (pembangunan) yang kegiatannya misalnya berada di Daerah lain (diluar DKI Jakarta), artinya faktor geografis menjadi kendala untuk melakukan pengawasan. 


\section{B. PERMASALAHAN}

Dari penjelasan di latar belakang terdapat informasi yang menunjukkan bahwa pelaksanaan kerjasama antara PemprovDKI Jakarta dengan PemprovJawa Tengah dalam penanganan PMKS tidak semua membuahkan hasil sebagaimana yang diharapkan, kendati pada awalnya program tersebut telah disepakati melalui perjanjian formal antar Gubernur. Dari pengamatan ketidak berhasilan tersebut disebabkan berbagai hal :

1. Terbatas pada political will artinya belum samanya visi dalam penanganan PMKS.

2. Programnya bukan merupakan kebutuhan (need) keduaDaerah.

3. Tidak didukung anggaran yang seimbang.

4. Problem sosial (PMKS) terus berkembang.

Oleh karena itu yang menjadi pokok permasalahan adalah "sejauh mana keberhasilan Kerjasama antara Pemerintah Propinsi DKI Jakarta dengan Propinsi Jawa Tengah dalam penanganan PMKS".

\section{PENDEKATAN PENELITIAN}

Penelitian ini bersifat deskriptif, yang tujuan utamanya melakukan evaluasi dan klarifikasi atas variabel-variabel pelaksanaan Kerjasama antara PemprovDKI Jakarta dengan PemprovJawa Tengah dalam Penanganan PMKS.

Penelitian deskriptif adalah penelitian yang bertujuan mendeskripsikan atau menjelaskan sesuatu hal seperti apa adanya (Prasetya Irawan , 1999 : 60) . Jadi perbedaan penelitian deskriptif dengan penelitian eksploratif terletak pada kedalaman penjelasannya, artinya fokus penelitian eksploratif pada pertanyaan bagaimana profil atau gambaran umum obyek penelitian ? Sedangkan penelitian deskriptif berfokus pada pertanyaan apa sebenarnya (apa esensi) obyek penelitian ini ? Oleh karena itu dalam penelitian deskriptif, penulis mempunyai kemungkinan untuk memilih satu obyek penelitian untuk dikaji secara mendalam dan bukan hanya membuat peta umum dari obyek penelitian tersebut.

Analisa dilakukan dengan mendeskripsikan dan menjelaskan proses penyelenggaraan dan pembinaan Kerjasama Antar Daerah oleh Pemda DKI Jakarta. Agar akurasi data yang bisa dijaring dapat diandalkan (reliable), maka teknik analisis permasalahan dalam penelitian ini dilakukan sekaligus menggunakan teknik-teknik statistik sederhana (tabulasi frekuensi) serta dilengkapi dengan teknik analisis kualitatif yang memanfaatkan hasil pengamatan dan wawancara mendalam dengan beberapa nara sumber (responden) untuk mendeskripsikan dan menjelaskan penyelenggaraan Kerjasama Antar Daerah.

Adapun yang dimaksud dengan metodologi kualitatif sebagai prosedur penelItian yang menghasilkan data deskriptif berupa kata-kata tertulis atau lisan dari orang-orang dan prilaku yang dapat diamati (Lexy J . Moleong, 1998 : 3). Dalam penelltian kualitatif pertanyaan "mengapa" menempati posisi yang lebih penting daripada pertanyaan tentang "apa" Untuk menghasilkan data deskriptif itu, penulis menggunakan metode survei dan metode evaluasi. 
Pengertian dari metode survey itu sendiri menurut Prasetya lrawan (1999 : 18) adalah : Metode (penelitian) yang menggunakan kuestioner sebagai instrument utama untuk mengumpulkan data.

Jadi pada penelitian survei, penggunaan kuestioner merupakan hal yang pokok untuk pengumpulan data. Hasil kuestioner tersebut akan terjelma dalam angka-angka, tabel-tabel, analisa statistik dan uraian serta kesimpulan hasil penelitian.

Penelitian dengan menggunakan metode survei ini dilakukan untuk berbagai maksud tertentu . Menurut Masri Singarimbun (1987:4) ada tujuh maksud dilakukannya penelitian dengan menggunakan metode survei yaitu : (1) penjajakan (eksploratif), (2) deskriptif, (3) penjelasan (explanatory atau confirmatory) yakni untuk menjelaskan hubungan kausal dan pengujian hIpotesa, (4) evaluasi, (5) prediksi atau meramalkan kejadian tertentu di masa yang akan datang, (6) penelitian operasional dan (7) pengembangan indikator-indikator sosial.

Dari ketujuh kegunaan dilakukannya surveI tersebut, kegunaan lainnya dari penelitian survei adalah untuk mengadakan evaluasi. Di sini yang menjadi Pertanyaan pokok adalah sampai seberapa jauh tujuan yang digariskan pada awal program tercapai atau mempunyai tanda-tanda akan tercapai - disinilah diperlukan penelitian evaluasi.

Masri Singarimbun (1987:5) mengatakan : Terdapat dua jenis penelitian evaluasi, yakni evaluasi Formatif dan evaluasi Summatif. Evaluasi Formatif biasanya melihat dan meneliti pelaksanaan suatu program, mencari umpan balik untuk memperbaiki pelaksanaan program tersebut. Evaluasi Summatif biasanya dilaksanakan pada akhir program untuk mengukur apakah tujuan program tersebut tercapai.

Metode evaluasi itu sendiri menurut Prasetya Irawan (1999 : 70) digunakan bila ingin menilai sesuatu dengan cara membandingkannya dengan suatu standar. Hasil dari penilaian ini mungkin digunakan untuk meningkatkan kualitas sesuatu yang dinilai itu atau membuat suatu keputusan .

\section{ANALISIS DATA DAN FAKTA}

Pada Bagian Kesatu telah dijelaskan bahwa penelltian ini bertujuan mengevaluasi pelaksanaan kerjasama antara Pemprov DKI Jakarta dengan Pemprov Jawa Tengah dalam upaya menanggulangi Penyandang Masalah KeseJahteraan Sosial (PMKS) . Oleh sebab itu penelitian ini tidak menggunakan responden populasi maupun dalam bentuk sampel, tapi langsung meneliti pendapat para pejabat dan unit yang langsung terkait dalam pelaksanaan Kerjasama Antar Daerah , khususnya yang menangani masalah PMKS.

Adapun alat bantu untuk mengevaluasi menggunakan faktor-faktor yang mendukung dan menghambat pelaksanaan kerjasama antara Pemerintah Propinsi DKI Jakarta dengan Propinsi Jawa Tengah dalam penanganan PMKS; apakah isi formulasi kesepakatan penanganan PMKS dilaksanakan; dan tahap-tahap penanganan PMKS melalui kerjasama antara Pemprov DKI Jakarta dengan Pemrov Jawa Tengah. 
Demi Untuk menjaga obyektifitas penilaian dan analisa maka penelitian dilaksanakan terhadap empat aspek yaitu : kelompok pengambilan kebijakan; kelompok pelaksanaan;kelompok pendukung dan kelompok masyarakat, dimana pertanyaan-pertanyaan dalam empat sisi yakni :

1. Pandangan responden terhadap visi, program anggaran dan pengawasan Kerjasama Antar Daerah ,

2. Pandangan responden terhadap penanganan PMKS melalui Kerjasama Antar Daerah,partisipasi instansi/unit lain terhadap program Kerjasama Antar Daerah.Saran agar program Kerjasama Antar Daerah berjalan dengan baik.

Dengan demikian yang menjadikan responden dalam penelitian ini adalah pejabat/unit serta tokoh masyarakat/pengurus LSM kedua Daerah (DKI Jakarta Jawa Tengah). Berdasarkan hal tersebut penulis memilih dan menetapkan responden sebagai berikut :

1. Asisten Ketataprajaan Propinsi DKI Jakarta - Jawa Tengah

2. Asisten Kesejahteraan Sosial Propinsi DKI Jakarta - Jawa Tengah

3. Ketua Bappeda Propinsi DKI Jakarta - Jawa Tengah

4. Kepala Bidang Sosbud Bappeda Propinsi DKI Jakarta- Jawa Tengah

5. Kepala Dinas Sosial Propinsi DKI Jakarta - Jawa Tengah

6. Kepala Sub Dinas Bina Program Propinsi DKI Jakarta - Jawa Tengah

7. Kepala Biro Bina Sosial Propinsi DKI Jakarta - Jawa Tengah

8. Kepala Dinas Tenaga kerja DKI Jakarta - Jawa Tengah

9. Kepala Biro Tata Pemerintahan Umum Propinsi Jawa Tengah

10. Kepala Biro Kerjasama Antar Kota dan Daerah Propinsi DKI Jakarta

11. Kepala Dinas Kependudukan Propinsi DKI Jakarta.

12. Kepala Bagian Kependudukan Biro Tata Pemerintahan umum Propinsi Jawa Tengah

13. Kepala Kanwil Transmigrasi propinsi DKI Jakarta - Jawa Tengah

14. Tokoh masyarakat/Pengurus LSM Bidang PMKS Propinsi DKI Jakarta -JawaTengah

Responden tersebut dibagi dalam 4 ( empat) kelompok, yaitu

A. Kelompok Perumus Kebijakan (policy) Kerjasama AntarDaerah

B. Kelompok Pelaksana Penanganan PMKS

C. Kelompok Pendukung Penanganan PMKS

D. Kelompok Tokoh Masyarakat/Pengurus LSM 


\section{Kelompok Perumus Kebijakan (policy) KerjasamaAntar Daerah}

Kelompok ini terdiri dari Asisten Ketataprajaan , Ketua Bappeda. Kepala Biro Tata Pemerintahan Umum Jawa Tengah dan Kepala Biro Kakda DKI Jakarta. Pejabat/unit ini masuk dalam Kelompok Kebijakan (policy), karena dalam tugas baik secara struktural maupun fungsional terlibat dalam penanganan Kerjasama Antar Daerah. Kepada kelompok ini peneliti ingin menggali jawaban tentang pandangan mereka terhadap visi Kerjasama Antar Daerah, program penanggulangan PMKS, dukungan anggaran dan pengawasan terhadap pelaksanaan program Kerjasama Antar Daerah.

\section{Kelompok Pelaksana Penanggulangan PMKS}

Kelompok ini terdiri dari Asisten Kesejahteraan Sosial, Kepala Dinas Sosial, Kepala Sub Dinas Bina Program Dinas Sosial, Kepala Bidang Sosial Budaya Bappeda, Kepala Biro Bina Sosial Pejabat/unit ini masuk dalam kelompok ini karena baik secara struktural maupun fungsional terlibat dalam penanggulangan PMKS. Kepada kelompok . ini peneliti ingin menggali jawaban sejauh mana pemahaman mereka terhadap tugas penaggulangan PMKS.

\section{Kelompok Pendukung Penanggulangan PMKS}

Kelompok ini terdiri dari Kepala Dinas Tenaga Kerja, Kepala Dinas Kependudukan dan Kepala Kanwil Transmigrasi. Pejabat/unit ini masuk dalam kelompok pendukung karena dalam pelaksanaan penanggulangan PMKS hanya bersifat khusus (adhoc), jadi tidak bersifat permanen/tetap. Kepada kelompok ini peneliti ingin menggali jawaban sejauh mana keterlibatan instansi/unitnya di dalam penaggulangan PMKS melalui Kerjasama Antar Daerah.

\section{Kelompok Tokoh Masyarakat/Pengurus LSM}

Kelompok initerdiri dari tokoh masyarakat dan pengurus LSM yang bergerak di bidang PMKS yang ada di Propinsi DKI Jakarta dan Propinsi Jawa Tengah. Kepada kelompok ini peneliti ingin menggali saran dan tanggapanterhadap penanggulangan PMKS Melalui kerjasama antar daerah. Efektifitas pelaksanaan kerjasama antara Pemprov DKI Jakarta dengan Pemprov Jawa Tegah dalam penanganan PMKS, dilihat dua tolok ukur, yaitu berjalannya pelaksanaan Kerjasama Antar Daerah dan keberhasilan dalam penanggulangan PMKS di DKI Jakarta yang berasal dari Jawa Tengah.

Oleh karena itu, dalam melakukan survei terhadap responden, peneliti disamping menggunakan daftar pertanyaan (questioner) juga melakukan wawancara dengan maksud agar jawaban yang diperoleh menjadi lengkap dan memenuhi syarat penelitian.

Melalui daftar pertanyaan dan wawancara yang dilakukan oleh peneliti diharapkan diperoleh jawaban dan tanggapan/respon mengenai hal-hal sebagai berikut : 
1. Tentang pelaksanaan Kerjasama Antar Daerah, seperti : kesamaan visi dan konsistensi terhadap Program, Anggaran yang telah disepakati dan Pengawasan terhadap kegiatan program Kerjasama Antar Daerah.

2. Tentang Penanggulangan PMKS, seperti : PMKS yang dikembalikan ke daerah asal (Jawa Tengah) apakah dapat disalurkan menjadi tenaga kerja, dapat berusaha sendiri di daerah asal dan mau ditransmigrasikan keluar dapat berusaha sendiri Propinsi Jawa Tengah.

\section{EVALUASI PELAKSANAAN KERJASAMA ANTARA PEMPROV DKI JAKARTA - PEMPROV JAWA TENGAH}

\section{Pandangan dari Sisi Penentu/Perumus Kebijakan}

Dari sisi penentu kebijakan kerjasama antar daerah, peneliti ingin mengetahui bagaimana tanggapan dan pemahaman mereka terhadap visi, program, anggaran, dan pengawasan pelaksanaan Penanganan PMKS.

\section{I S I}

Visi dalam suatu organisasi/kegiatan sangat diperlukan karena dengan adanya Visi, kegiatan akan lebih terarah dan dapat membantu menyelesaikan rnasalah serta hasilnya dapat diukur.

Dari hasil penelitian rnenunjukkan bahwa Pemprov DKI Jakarta dan Jawa Tengah rnempunyai Visi yang sama dalam pelaksanaan Kerjasarna Antar Daerah. Kerjasama antara kedua Daerah penting dalam rangka menanggulangi masalah yang berkaitan dengan kedua Daerah. Visi tersebut dituangkan dalam pernyataan (statement) masing-masing Daerah, yaitu Pemprov DKI Jakarta : "Dapat menyelesaikan Masalah Bersama yang dihadapi Kedua Daerah ", sedangkan Pemprov Jawa Tengah adalah : "Dapat Menyelesaikan Masalah Bersama Daerah, guna meningkatkan PAD, SDM dan kemandirian Daerah".

Untuk melihat sejauh mana penjabaran Visi Kerjasama antara Pemprov DKI Jakarta - Pemprov Jawa Tengah dalam upaya menyelesaikan masalah bersama, atau mencari solusi dalam penanggulangan PMKS, serta arah/pedoman yang ditempuh dalam pelaksanaannya dalam dalam upaya rnencapai sasaran/tujuan Kerjasama maka tabel berikut ini , akan memberi gambaran secara garis besar : 
Tabel 1

\section{JAWABAN RESPONDEN TERHADAP VISI}

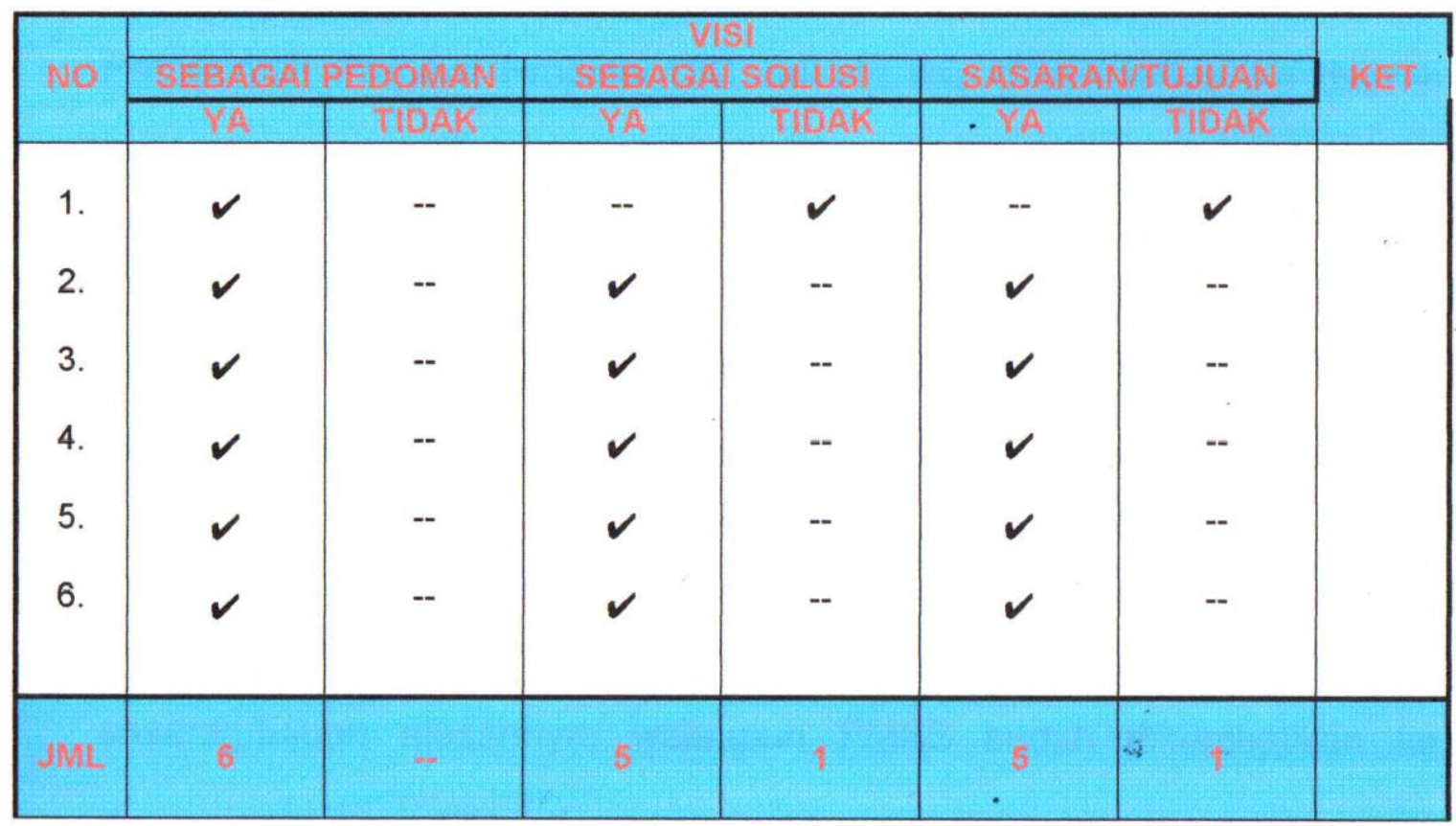

Tabel 1 tersebut dapat menjelaskan dari kelompok kebijakan sebanyak 6 orang yang diwawancarai semua menyatakan setuju visi Kerjasama Antar Daerah dapat dijadikan pedoman/arah dalam menyelesaikan masalah yang dihadapi oleh kedua Daerah terutama dalam penanganan PMKS. Tabel ini sejalan dengan pendapat Warren Bennis \& Michel Mische yang mengatakan bahwa visi itu merupakan artikulasi dari citra, nilai, arah dan tujuan yang akan memandu masa depan organisasi ( $1999: 59$ ).

Visi sebagai solusi dalam membantu menyelesaikan masalah oleh responden sebanyak 5 (lima) orang menyatakan bahwa visi dapat membantu menyelesaikan masalah alasannya karena setiap operasi penertiban PMKS yang dilakukan oleh Pemprov DKI Jakarta dan Dikembalikan ke daerah asal (Propinsi Jawa Tengah) tidak ditindak lanjuti oleh propinsi Jawa Tengah sehingga PMKS kembali lagi ke Jakarta.

Sedangkan sejauhmana sasaran/tujuan Kerjasama Antar Daerah dapat dicapai dengan adanya visi, responden menjawab bahwa setuju sebanyak 5 (lima) orang. Visi yang ditetapkan itu telah mencapai sasaran/tujuan, hanya satu orang menyatakan bahwa belum tercapai sasaran/tujuan alasannya, walaupun PMKS sudah dikembalikan ke daerah asal Jawa Tengah, tapi Kota Jakarta tetap masih banyak PMKS. Dari analisa tersebut dapat ditarik kesimpulan bahwa visi Kerjasama Antar daerah yaitu "Menyelesaikan masalah yang dihadapi kedua 
Daerah", ternyata sudah tepat, artinya dengan visi yang ditetapkan oleh masing-masing daerah dapat dijadikan pedoman/arah di dalam dihadapi oleh kedua daerah sehingga menyelesaikan masalah yang sasaran/tujuan dapat dicapai.

\section{a. Program}

Proses penyusunan Program kerjasama Antar Daerah pada tahap awal didahului saling pada tukar-menukar informasi tentang potensi kedua Daerah, informasi Yang diperoleh tersebut dibahas oleh Daerah untuk menetapkan materi/bidang apa yang akan dikerjasamakan. Setelah disepakati bidang/materi yang akan dikerjasamakan baru dilakukan studi kelayakan (field study) untuk menentukan manfaat dari Program yang akan dikerjasamakan. Dalam merumuskan Program Kerjasama Antar Daerah prinsip yang dianut adalah win-win solution, bersinerji terhadap pembangunan kedua Daerah. Sehingga diharapkan Program yang ditetapkan itu dapat mencapai sasaran/tujuan.

Untuk jelasnya apakah Program Kerjasama Antar Daerah itu didahului dengan study kelayakan, apakah program merupakan suatu kebutuhan (need), dapat dilihat pada tabel berikut dibawah ini.

\section{Tabel 2}

\section{JAWABAN RESPONDEN TERHADAP PROGRAM}

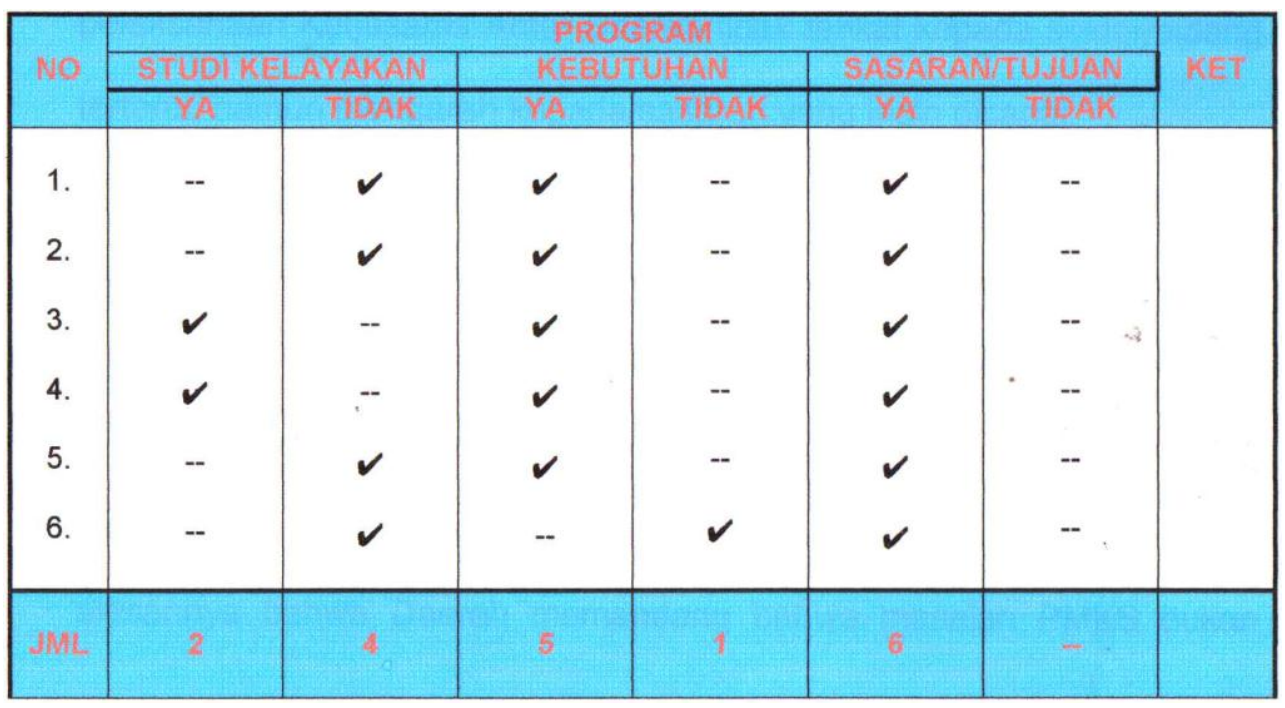

Tabel 2 tersebut dapat menjelaskan bahwa dari kelompok kebijakan sebanyak 6 (enam) orang yang diwawancarai hanya 2 orang mengatakan bahwa Program Kerjasama Antar Daerah didahului dengan suatu penelitian. Hal ini terjadi karena Pemda terikat dengan asas legalistik artinya daerah terikat dengan mekanisme penyusunan Program Pembangunan Daerah yaitu ; Rakorbang I - Rakorbang II 
dan Seterusnya. Mekanisme penyusunan program daerah tersebut terkadang tidak dapat disamakan dengan mekanisme persidangan Ratek (Rapat Teknis) kelompok kerja kerjasama antar Daerah Pemprov DKI Jakarta - Pemprov Jawa Tengah dengan penegertian lain pengusulan DUK (Daftar Usulan Kegiatan) maupun DUP (Daftar Usulan Proyek) dengan jadwal Rapat Teknis (Ratek) tidak sinkron.

Disamping itu pelaksanaan study kelayakan yang dilaksanakan selama ini masih bersifat "mikro teknis" belum mengarah kearah "makro teknis", sehingga belum bersifat komperhensif. Itulah sebabnya hasil pelaksanaan kerjasama antar daerah tidak terikat kepada sektor/bidang tertentu namun mengarah kepada sasaran yang ingin dicapai.

Program Kerjasama Antar Daerah yang disusun berdasarkan suatu kebutuhan kedua Oaerah oleh responden dinyatakan ya sebanyak 5 (lima) orang artinya mereka menyadari bahwa program penanganan PMKS didasarkan kebutuhan kedua daerah. Sedangkan responden yang menyatakan bukan merupakan kebutuhan sebanyak 1 (satu) orang alasannya bahwa Daerah memandang bahwa masalah PMKS bukan merupakan prioritas untuk diprogramkan. Oleh karena itu program Kerjasama Antar Daerah ini sifatnya bukan dadakan, artinya bukan keinginan semata oleh pimpinan tapi memang masalah PMKS Perlu ditanggulangi melalui Kerjasama antar Daerah .

Dari uraian diatas dapat ditarik kesimpulan bahwa Program Kerjasama Antara Pemprov DKI Jakarta dengan Pemprov Jawa Tengah dalam penanganan PMKS tidak didahului dengan suatu studi kelayakan/penelitian artinya Program tersebut bukan merupakan suatu kebutuhan . Alasannya karena pada rapat suatu hasil kajian yang bersifat ilmiah. forum kerjasama antar Gubernur se Jawa dan Bali• (Sad Praja Utama), ada tahapan-tahapan pembahasan program kerjasama antar bidang/sektor. Pada tahap I disebut dengan Rapat Teknis (Ratek) 1 yang mengevaluasi pelaksanaan program kerjasama tahun yang lalu. Peserta Ratek I terdiri dari tingkat pimpinan Pemerintah Propinsi yaitu para Asisten Ketataprajaan, Kepala Biro Tata Pemerintahan Umum, Kepala Biro Kakda, Kepala Bidang Sosial Budaya Bappeda, Kantor Penghubung Pemerintah Propinsi se Jawa dan Bali. Tahap II disebut dengan Rapat Teknis (Ratek) II membahas program antar bidang/sektor maupun Dinas/Unit untuk dilaksanakan pada tahun berikutnya. Peserta Ratek II terdiri dari peserta Ratek I ditambah dengan kepala Dinas SosialPeternakan, Kependudukan, Tenaga Kerja, Transmigrasi, Pertanian, Kehutanan, dan lain-lain yang sifatnya teknis. 
Tahap IIIdisebut pra Raker Gubernur membahas dan menyempurnakan konsep-konsep kesepakatan kerjasama antar bidang/ sektor yang ditetapkan pada Ratek II . Peserta Pra Raker terdiri dari peserta Ratek II ditambah dengan para Ketua Bappeda dan Sekda Propinsi.

Tahap IV disebut Raker Gubernur membahas program Kerjasama Antar Daerah dan sekaligus menandatangani kesepakatan program kerjasama yang akan dilaksanakan pada tahun yang akan datang . Peserta Raker Gubernur terdiri dari peserta Pra Raker Gubernur ditambah dengan para Gubernur.

Dari uraian tersebut diatas dapat dilihat bahwa ternyata program yang dibahas oleh Dinas/unit kedua daerah pada Ratek/Raker sifatnya legalistik dan menganut asas skala prioritas ini terjadi karena pembahasan program hanya merupakan usulan dari dinas/unit Daerah, sehingga hasil pembahasan program bukan merupakan suatu hasil kajian, melainkan hasil kesepakatan untuk melaksanakan kegiatan bersama.

Dari segi keterlibatan DPRD (Legislatif) dapat dilihat bahwa dalam pembahasan program penanganan PMKS melalui kerjasama antar Daerah ternyata belum terlihat keterlibatan DPRD (Legislatif) sebagaimana yang diamanatkan oleh Pasal 87 ayat (4) Undang-Undang No. 22 Tahun 1999 mengatakan : Keputusan bersama dan/atau Badan Kerjasama, Sebagaimana pada ayat (1), ayat (2), dan, ayat (3) yang membebani masyarakat dan Daerah harus mendapatkan persetujuan DPRD masing-masing.

Ketidak terlibatan DPRD dalam pembahasan program, karena kerjasama antara Pemprov DKI Jakarta Dengan Pemprov i Jawa Tengah yang ditandatangani tahun 1991 masih menggunakan Undang-Undang No. 5 Tahun 1974, dimana dalam pembahasan program kerjasama antar daerah keterlibatan DPRD tidak seperti yang diinginkan oleh pasal 87 ayat (4). Oleh karena itu keterlibatan DPRD (Legislatif) dalam pembahasan program kerjasama antar daerah tersebut diatas berdasarkan Pasal 87 dapat dilihat pada saat program tersebut diajukandalam bentuk pembahasan Rancangan Peraturan Daerah APBD (RAPBD) pada Komisi A .

Selanjutnya dari segi hirarki koordinasi kerjasama antar Propinsi dengan Kabupaten sebagai konsekuensi diberlakukannya UndangUndang Nomor 22 Tahun 1999, ternyata antara Pemprov Jawa Tengah (Dinas Sosial Propinsi) dengan Panti Sosial Samekto Karti Comal Kabupaten Pemalang tidak menjadi masalah, karena Panti Sosial Samekto karti merupakan Unit Pelaksana Teknis (UPT) Dinas Sosial Pemprov Jawa Tengah. Sehingga didalam pelaksanaan program penanganan PMKS ini, antara Pemprov Jawa Tengah dengan Kabupaten Pemalang sifatnya koordinasi dan itu sudah berjalan dengan baik. 
Dinas Sosial Kabupaten Pemalang menangani PMKS yang berada diluar Panti Sosial Samekto Karti artinya PMKS yang berada di Kabupaten Pemalang, sehingga apabila Pemerintan Kabupaten Pemalang ingin melakukan kerjasama dengan Pemprov DKI Jakarta dalam penanganan PMKS dapat dilaksanakan tanpa melalui Pemprov Jawa Tengah karena Kabupaten Pemalang bukan lagi merupakan bawahan (hirarki) Pemprov, Jawa Tengah (sesuai dengan Undang-Undang Nomor 22 Tahun 1999)

\section{b. Anggaran}

Pelaksanaan program Kerjasama Antar Daerah akan lebih baik bila didukung oleh anggaran Daerah (APBD) secara konsisten, artinya program yang sudah disepakati oleh kedua Gubernur (Pemprov DKI Jakarta - Pemprov Jawa Tengah) dalam satu keputusan bersama, seyogyanya dialokasikan dalam APBD kedua Daerah. Dengan konsistensi dukungan anggaran akan dapat dicapai sasaran/tujuan Kerjasama Antar Daerah.

Untuk menjelaskan apakah kedua Daerah memberikan dukungan anggaran terhadap program Kerjasama Antar Daerah, serta adanya konsistensi dapat dilihat pada tabel dibawah ini.

\section{Tabel 3}

\section{JAWABAN RESPONDEN TERHADAP ANGGARAN}

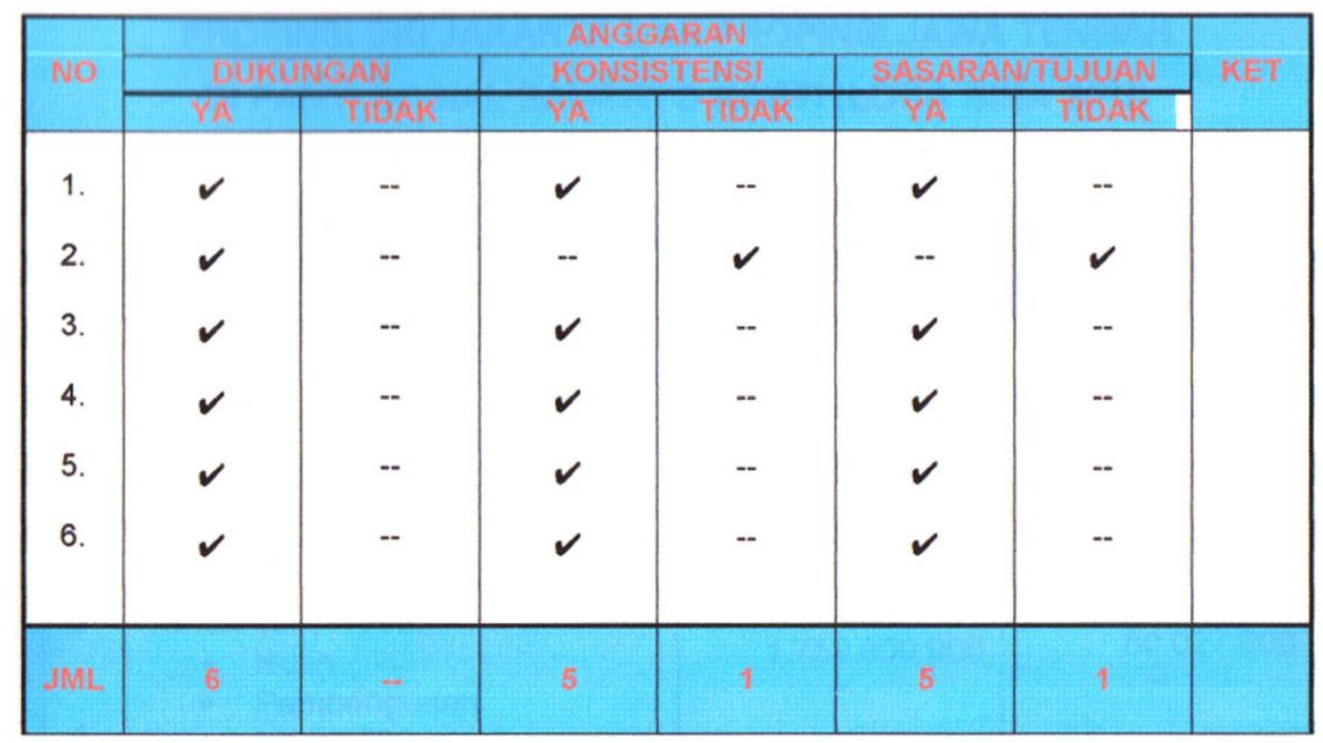

Tabel 3 tersebut dapat menjelaskan dari kelompok kebijakan sebanyak 6 (enam) orang yang diwawancarai semua (100\%) mengatakan Daerah memberikan dukungan terhadap pelaksanaan Kerjasama Antar Daerah. Dukungan diberikan berdasarkan kemampuan anggaran masing-masing daerah dan ada yang diberikan berdasarkan pada prinsip skala prioritas, sehingga 
kadang-kadang mengalahkan prinsip kebutuhan. Untuk jelasnya dukungan anggaran diberikan Daerah terhadap PMKS melalui Kerjasama antar Pelaksanaan program Penanggulangan Daerah dapat dilihat pada tabel berikut.

Tabel 4

ANGGARAN RUTIN/PEMBANGUNAN PEMPROV DKI JAKARTA DARI PEMPROV DKI JAKARTA DAN PEMPROV JAWA TENGAH DI PANTI SOSIAL SAMEKTO KARTI (LOKA BINA SPU) COMAL KAB. PEMALANG JAWA TENGAH

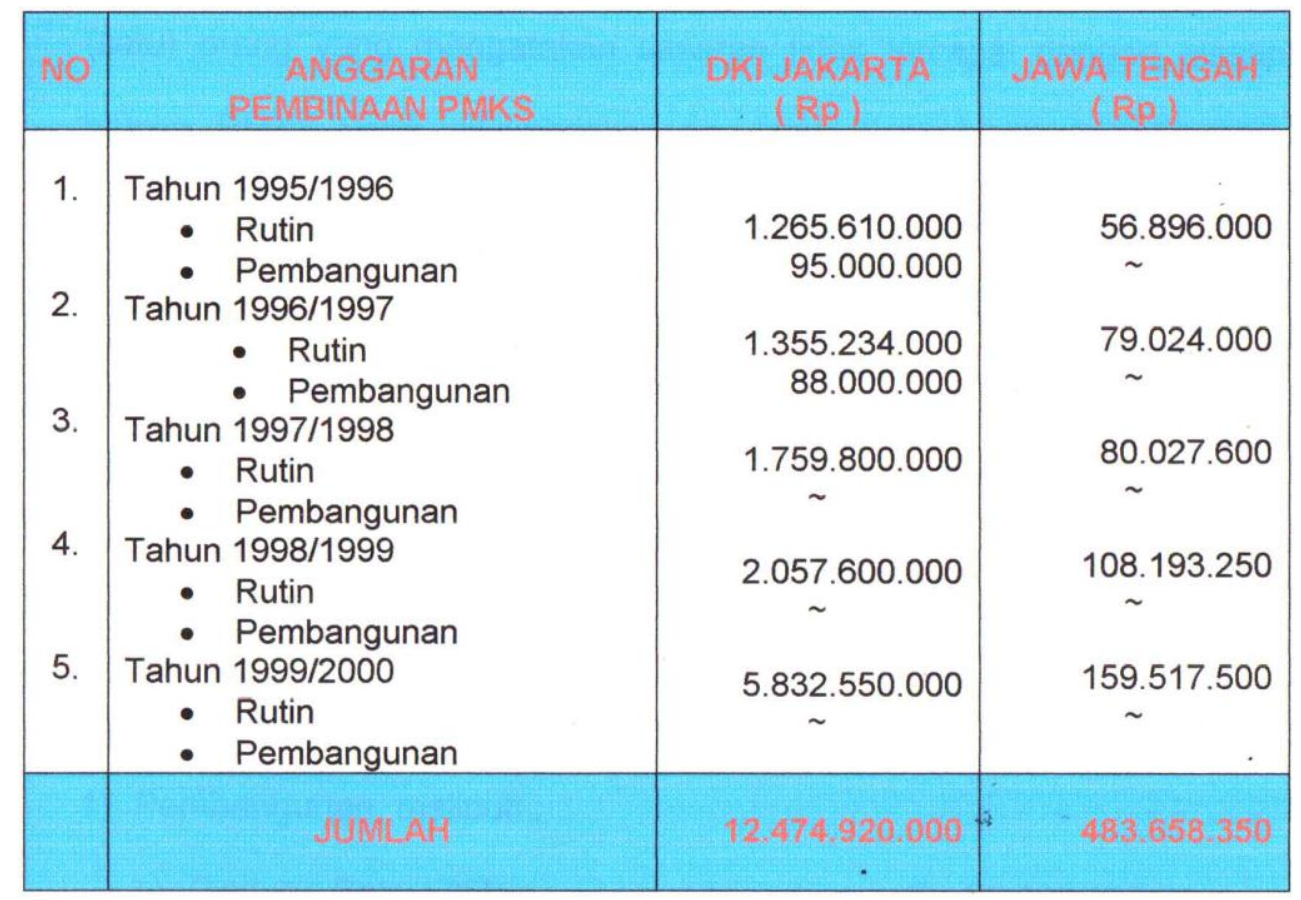

Tabel 4 tersebut diatas menjelaskan bahwa anggaran rutin cenderung naik tiap tahun, juga terlihat Pemprov DKI Jakarta memberikan dukungan tidak hanya dalam bentuk anggaran rutin, tapi juga dalam bentuk pembangunan (proyek). Demikian juga tabel 4 menjelaskan bahwa Daerah konsisten daiam melaksanakan kesepakatan ini dinyatakan sebanyak 5 (lima) orang, hanya 1 (satu) orang menyatakan tidak konsisten alasannya bahwa masalah PMKS untuk propinsi Jawa tengah bukan merupakan prioritas.

Mengenai sasaran/tujuan responden menyatakan bahwa 5 (lima) orang mengatakan bahwa sasaran /tujuan dapat dicapai, hanya 1 (satu) orang yang mengatakan sasaran tidak tercapai dengan alasan bahwa PMKS yang dikembalikan ke Jawa Tengah masih ada yang kernbali lagi ke Jakarta. Adanya PMKS yang kembali lagi ke 
Jakarta antara lain dikarenakan skill/kemampuannya untuk bekerja di Jakarta sudah memenuhi setelah dibina di Panti Comal, atau tingkat pendapatannya lebih rendah bila dibanding menjadi PMKS di Jakarta.

Dukungan anggaran terhadap program penanganan PMKS, baik anggaran pembangunan maupun anggaran pembinaan (rutin) oleh Panti Sosial Samekto Karti digunakan untuk :

1) Pembangunan, meliputi :

a) Gedung Balai Latihan $\quad \mathrm{Rp} 95.000 .000,00$

b) Pembangunan pagar $\quad \mathrm{Rp} 88.000 .000,00$

c) Pembangunan Gedung lsolasi $\quad \mathrm{Rp} 30.000 .000,00$

2) Pembinaan, meliputi :

a) Anggaran Pelatihan Pertukangan Kayu

b) Anggaran Pelatihan pertukangan Batu

c) Anggaran Pelatihan Pertanian

d) Anggaran Pelatihan Peternakan

e) Anggaran Perdagangan /usaha Kecil

3) Rutin, meliputi :

a) Anggaran makan penghuni panti

b) Anggaran kesehatan/ pengobatan

c) Ongkos pemulangan ke desa asal

Sedangkan anggaran yang digunakan oleh Pemerintah Propinsi DKI Jakartadalampenanganan PMKS, untuk:

1) Pengumpulan PMKS, meliputi :

a) Anggaran penyuluhan

b) Anggaran penertiban

2) Penampungan PMKS sernentara, meliputi :

a) Anggaran identifikasi

b) Anggaran penseleksian

c) Anggaran pembinaan sosial

3) Pemulangan ke daerah asal, meliputi :

a) Anggaran koordinasi/konsultasi ke daerah asal

b) Anggaran pengantaran PMKS

\section{c. Pengawasan}

Pelaksanaan Kerjasama Antar Daerah akan berdaya guna dan berhasil guna, bila dilakukan pengawasan secara tepat, artinya Pengawasan yang dilaksanakan mempunyai prosedur tetap (protap). Protap ini merupakan mekanisme yang digunakan dalam melakukan Pengawasan pelaksanaan kegiatan program kerjasama antara Pemprov DKI Jakarta dengan Pemprov Jawa Tengah dalam penanganan PMKS. Disamping masalah Protap (Prosedur Tetap) pengawasan, diperlukan juga monitoring dan evaluasi/penilaian dalam pelaksanaan Kerjasama Antar Daerah, ini berkaitan dengan 
sampai seberapa jauh sasaran/tujuan Kerjasama Antar Daerah itu dapat dicapai.

Untuk mengetahui apakah pengawasan dan evaluasi terhadap pelaksanaan Kerjasama Antar Daerah sudah dila ksanakan dengan baik dan tepat atau dengan pengertian lain apakah pengawasan, monitoring dan evaluasi diperlukan dapat dilihat pada tabel dibawah ini.

\section{Tabel 5}

\section{JAWABAN RESPONDEN TERHADAP PENGAWASAN}

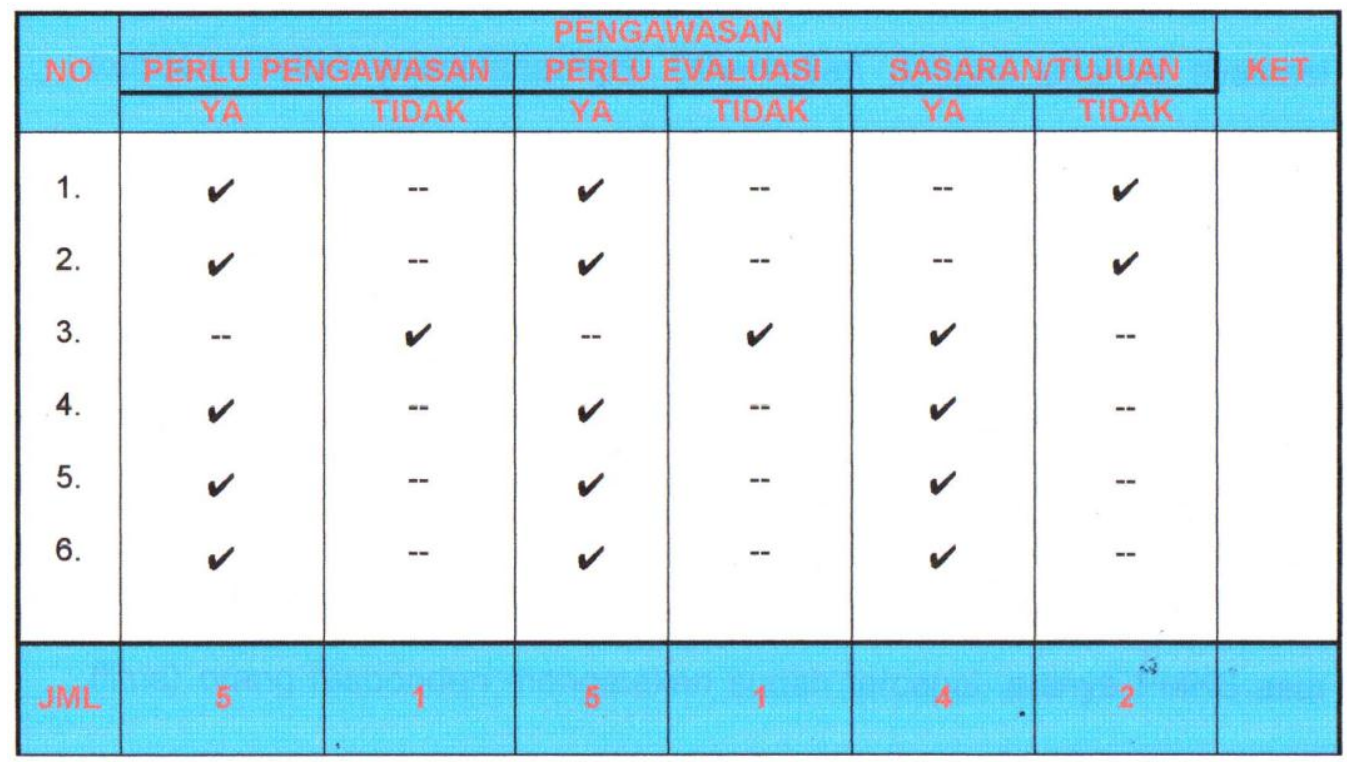

Tabel 5 tersebut menjelaskan dari seluruh reponden hanya 1 ( satu) orang mengatakan bahwa pengawasan tidak diperlukan, alasannya karena dalam melaksanakan Program Kerjasama antara Pemprov DKI Jakarta dengan Pemprov Jawa Tengah belum ada prosedur tetap (protap) yang dijadikan acuan untuk melaksanakan pengawasan. Sehingga bila akan dilaksanakan pengawasan sebagaimana fungsi -fungsi manajemen, pelaksanaannya tidak berjalan dengan benar.

Demikian juga mengenai evaluasi terhadap pelaksanaan kerjasama antara Pemprov DKI Jakarta dengan Propinsi Jawa Tengah sebanyak 5 (lima) orang responden mengatakan diperlukan evaluasi terhadap pelaksanaan kerjasama tersebut alasannya agar pimpinan (Gubernur) dapat mengetahui sampai sejauhmana keberhasilan program Kerjasama Antar Daerah dan mengetahui apa yang menjadi kendala dalam pelaksanannya. Diharapkan dengan adanya evaluasi akan ada kebijakan baru dari Gubernur tentang kerjasama antar daerah. 
Dari jumlah responden yang diwawancarai ternyata 1 (satu) orang mengatakan evaluasi tidak dapat dilaksanakan dengan alasan bahwa tidak jelas aspek-aspek mana yang akan dievaluasi. Mengenai sasaran/tujuan apakah pengawasan diperlukan dalam penanganan PMKS sebagai konsekuensi dari Kerjasama Antar Daerah, sebanyak 5 (lima) orang responden mengatakan sudah tercapai, artinya PMKS asal Jawa Tengah yang dimembalikan dan dibina sudah kembali ke desa asal dan berusaha sendiri (mandiri), ada yang mngikuti program transmigrasi dan ada yang disalurkan menjadi tenaga kerja. Sedangkan 1 (satu) orang mengatakan bahwa program penanganan PMKS melalui kerjasama antar Daerah belum mencapai sasaran/tujuan alasannya karena PMKS yang telah dibina di panti Sosial Samekto Karti dan telah dimasyaraatkan tidak di monitor perkembangannya.

\section{Pandangan Dari Sisi Pelaksana Program (PMKS)}

Dari sisi pelaksana pro gram penanganan PMKS, penulls ingin mengetahui sampai sejauh mana pemahaman mereka terhadap tugas dalam penanganan PMKS, artinya bagaimana responden terlibat mulai dari persiapan, pelaksanaan dan pembinaan .

\section{a. Tanggapan TerhadapVisi}

Dari hasil wawancara peneliti dengan responden tentang Visi dalam penanganan PMKS melalui kerjasama antara Pemprov DKI Jakarta dengan Pemprov Jawa Tengah, mereka mempunyai Visi masing-masing.

Dinas Sosial Pemprov DKI Jakarta mempunyai Visi dalam pelaksanaan kerjasama antara Pemerintah Propinsi DKI Jakarta dengan Pemprov Jawa Tengah, visinya : "Meningkatkan harkat, martabat dan harga diri PMKS untuk hidup secara tayak, normatif dan manusiawi", sedangkan Visi Propinsi Jawa Tengah adalah : "Kesejahteraan sosial oleh dan untuk seтиа тепији keadilan sosial dalam kehidupan dan Penghidupan masyarakat". Untuk mengetahui sejauh mana Visi tersebut dapat dijadikan sebagai arah/pedoman dalam Menyelesaikan masalah PMKS.

Visi sebagai solusi dalam membantu menyelesaikan masalah Sebanyak 8 (delapan) orang responden menyatakan bahwa visi dapat rnernbantu menyelesaikan masalah, dan hanya 2 (dua) orang mengatakan visi tersebut tidak dapat membantu menyelesaikan masalah, alasannya karena visi yang dirumuskan terlalu konsepsional sifatnya, sehingga sulit mengoprasionalkannya; tidak adanya tindak lanjut dari Pemprov Jawa Tengah terhadap PMKS yang dikembalikan, instansinya tidak terlibat dalam merumuskan visi. 
Sejauhmana sasaran/tujuan kerjasama antar Daerah dapat dicapai dengan adanya visi, responden menjawab bahwa yang setuju sebanyak 6 (enam) orang, artinya responden berpendapat bahwa sasaran/tujuan penanggulangan PMKS melalui kerjasama antara Pemprov DKI Jakarta dengan Pemprov Jawa Tengah memang sudah mencapai sasaran/tujuan, sedangkan 4 (empat) orang menyatakan bahwa sasaran/tujuan belum tercapai, alasannya belum teruji sampai sejauhmana tingkat keberhasilan PMKS yang telah dibina di Panti Samekto Karti Comal Pemalang Jawa Tengah hidup di tengah masyarakat, artinya apakah PMKS yang sudah disalurkan menjadi tenaga kerja hanya sekedar dapat pekerjaan atau memang keahlian yang didapat dari Panti sesuai dengan pekerjaannya itu, demikian juga dengan usaha mandiri apakah usaha tersebut sudah dapat memenuhi kebutuhan hidup layak.

Dari analisa tersebut dapat ditarik kesimpulan bahwa visi kerjasama antar Daerah dalam kerjasama antar Daerah yang dirumuskan oleh kedua Daerah dalam penanganan PMKS, ternyata sudah tepat, artinya bahwa visi tersebut dapat dijadikan arah/pedoman

\section{b. Keterlibatan Dalam Penanganan PMKS}

Keterlibatan instansi/unit kedua Daerah (DKI Jakarta - Jawa Tengah) dalam penanganan PMKS Penting, karena dengan adanya koordinasi akan memudahkan pelaksanaan tugas. Keterlibatan yang akan digali oleh penulis adalah sejauhmana responden ikut dan apa perannya mulai dari persiapan, pelaksanaan dan pembinaan.

Untuk menjelaskan sejauhmana keterlibatan instansi/unit kedua daerah dalam penanganan PMKS, dapat dilihat pada tabel berikut. 


\section{Tabel 6}

\section{JAWABAN RESPONDEN TERHADAP KETERLIBATAN INSTANSI/UNIT}

\begin{tabular}{|c|c|c|c|c|c|c|c|}
\hline & $x_{n}$ & & IERLES & & & & \\
\hline 10 & +8 & An & D PHA & KSANAAN & D & HNAN & KE: \\
\hline & & & & & & & \\
\hline 1. & - & $v$ & - & $v$ & $v$ & - & \\
\hline 2. & $v$ & - & - & $v$ & $v$ & -- & \\
\hline 3. & -- & $\sigma$ & $v$ & -- & -- & $\checkmark$ & \\
\hline 4. & - & $v$ & $v$ & -- & - & $v$ & \\
\hline 5. & $v$ & -- & $v$ & -- & -- & $\checkmark$ & \\
\hline 6. & $\checkmark$ & - & - & $v$ & - & $\checkmark$ & \\
\hline 7. & $v$ & - & - & $v$ & -- & $v$ & \\
\hline 8. & $\checkmark$ & - & 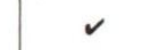 & -- & $v$ & -- & \\
\hline 9. & $\sigma$ & - & $v$ & -- & $\checkmark$ & -- & \\
\hline 10. & $\checkmark$ & - & -- & 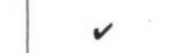 & $v$ & - & \\
\hline & 7 & 3 & 5. & 5 & 5 & 5 & \\
\hline
\end{tabular}

Tabel 6 tersebut dapat menjelaskan bahwa pelaksana kelompok sebanyak 10 (sepuluh) orang yang diiwawancarai sebanyak 7 (tujuh) orang menyatakan terlibat mulai dari persiapan Sedangkan 3 (tiga) orang menyatakan tidak terlibat dalam arti fisik alasannya karena status/jabatan responden. Kegiatan persiapan dilakukan oleh Tim Kerja Sosial yang dibentuk oleh kedua Daerah. Tugas Tim Sosial dalam persiapan antara lain memberikan penyuluhan sosial dan penertiban . Kegiatan ini sering disebut dengan pengumpulan PMKS biasanya kegiatan pengumpulan PMKS dilakukan di Jakarta sebagai daerah pengirim PMKS.

Adapun keterlibatan dalam pelaksanaan penanganan PMKS, ternyata sebanyak 5 (lima) orang responden menjawab terlibat dan 5 (lima) orang lagi menyatakan tidak terlibat. lni terjadi karena persepsi responden yang tidak sama tentang arti keterlibatan. Sebab hasil wawancara penulis dengan responden, mereka beranggapan bahwa keterlibatan dalam pelaksanaan artinya terlibat secara fisik, padahal yang dimaksud terlibat dalam penelitian ini adalah mereka/instansi yang tupoknya memang menangani PMKS.

Kegiatan dalam pelaksanaan biasanya diawali dengan Penyuluhan dan penertiban penyuluhan dilaksanakan pada PMKS yang berada di tengah masyarakat, sedang penertiban dilaksanakan pada PMKS yang berada di jalanan. Dari hasil 
penyuluhan dan penertiban dipilah mana PMKS yang potensial dan non potensial. Ke semua PMKS tersebut dilayani baik di Panti maupun diluar Panti.

Bentuk pelayanan yang diberikan terhadap PMKS tersebut antara lain memberikan pembinaan sosial, pembinaan mental, pelatihan ketrampilan , bantuari simulasi dan kemandirian. Setelah dilakukan pelayanan barulah dipulangkan ke daerah asal (Jawa Tengah) tepatnya ke Panti Sosial Samekto Karti Kabupaten Pemalang Jawa Tengah, disinilah keterlibatan unit/instansi Pemprov Jawa Tengah. Keterlibatan dalam pembinaan terhadap PMKS dari wawancara yang dilakukan oleh penulis kepada responden, ternyata 5 (lima) orang responden mengatakan ikut dalam pembinaan PMKS yang dilakukan melalui kerjasama antara Pemprov DKI Jakarta dengan Pemprov Jawa Tengah.

Kegiatan pembinaan yang dilakukan terhadap PMKS meliputi pembinaan mental sosial dan ketrampilan, penyaluran dan pembinaan lebih lanjut dan terminasi. Ini dilaksanakan di daerah asal PMKS yakni di Panti Samekto Karti Comal Jawa Tengah.

Dari uraian tersebut dapat ditarik kesimpulan bahwa instansi/unit yang menangani PMKS ternyata instansi/pejabat Pemprov DKI Jakarta terlibat mulai dari persiapan sampai kepada pembinaan dalam penanganan PMKS melalui kerjasama antara Pemprov DKI Jakarta dengan Pemprov Jawa Tengah yang menjadi masalah adalah pembinaan lebih lanjut oleh Pemprov Jawa Tengah terhadap PMKS sebagaimana gambar 4 tahap IV tidak dilaksanakan. Ini dapat dilihat dari anggaran yang tersedia untuk pembinaan PMKS di Panti Samekto Karti Comal sangat rendah dan kegiatan MONEV (Monitor dan Evaluasi) oleh pemerintah propinsi Jawa Tengah tidak dilakukan terhadap PMKS yang telah dimasyarakatkan.

\section{Pandangan Dari Sisi Instansi Pendukung}

Dari sisi instansi/unit pendukung kerjasama antara Pemerintah Propinsi DKI Jakarta dengan Propinsi Jawa Tengah dalam penanganan PMKS, penulis ingin mengetahui sejauhmana keterlibatan instansi/unit dalam program kerjasama antara Pemprov i DKI Jakarta dengan Pemprov Jawa Tengah, artinya apakah instansinya terlibat dalam persiapan, pelaksanaan dan pembinaan PMKS.

a. Keterlibatan Dalam Program Kerjasama antara Pemprov DKI Jakarta dengan Pemprov Jawa Tengah. 
Hasil wawancara yang dilakukan oleh penulis kepada responden sebanyak 6 (enam) orang, ternyata instansi/unit pendukung ada yang ikut mulai dari persiapan sampai dengan pembinaan - hanya tidak secara rutin , artinya tergantung kepada kesiapan pengusulan program dan anggaran . Untuk lebih jelasnya, tabel berikut dapat menjelaskannya.

Tabel 7

JAWABAN RESPONDEN TERHADAP KETERLIBATANINSTANSI/UNIT

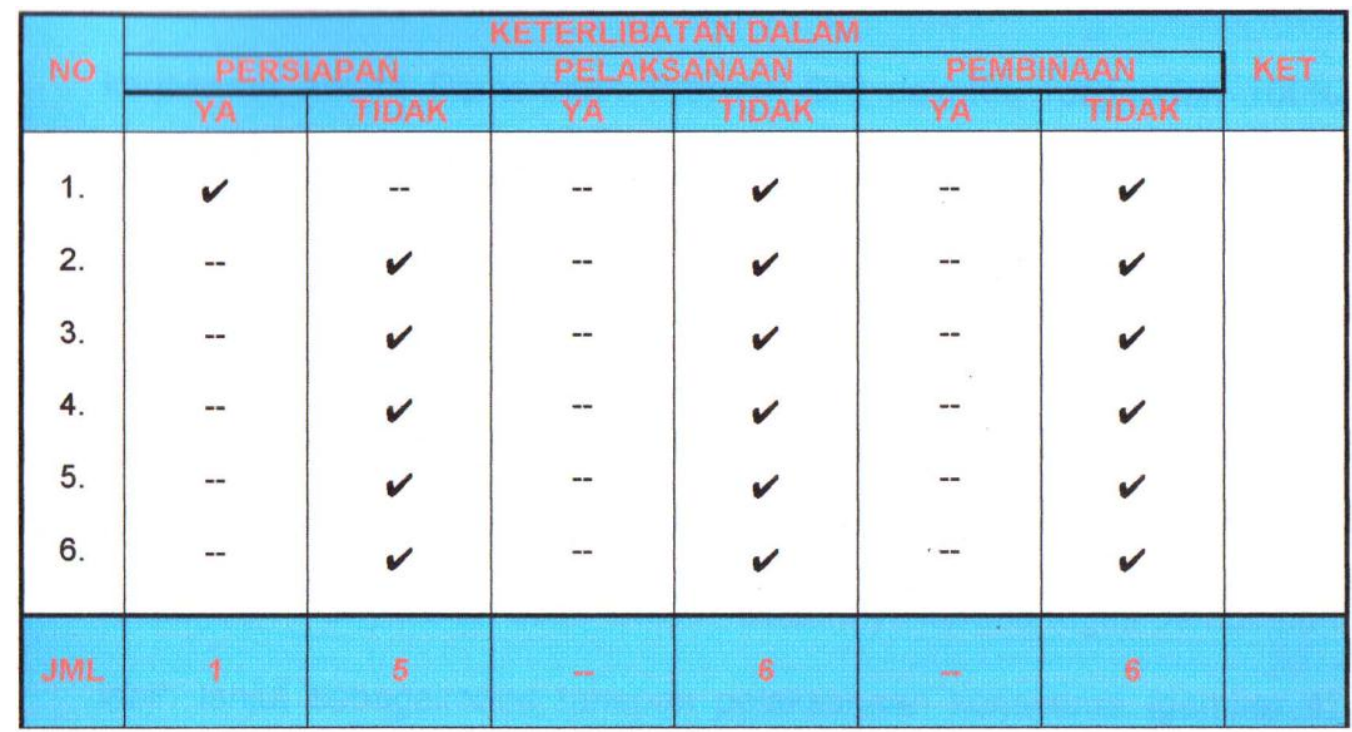

Tabel 7 tersebut dapat menjelaskan bahwa kelompok pendukung sebanyak 5 (lima) orang menyatakan tidak terlibat dalam persiapan program kerjasama antara Pemprov DKI Jakarta dengan Pemprov Jawa Tengah dalam penanganan PMKS, alasannya memang tupoknya bukan menangani masalah PMKS dan bahkan dari hasil wawancara menunjukkan bahwa ketidak-ikutan responden dalam persiapan, karena tidak dilibatkan, adapun 1 (satu) orang responden yang terlibat dalam persiapan program kerjasama antara Pemprov DKI Jakarta dengan Pemprov Jawa Tengah, alasannya karena instansinya duduk dalam Badan Koordinasi Pengendalian Urbanisasi (BAKOPUR) DKI Jakarta pada tahun 1995_ Oleh karena itu keterlibatan instansi/unit pendukung dalam program kerjasama sifatnya tidak permanen (menetap) ·

Dalam pelaksanaan program penanganan PMKS melalui kerjasama antara Pemprov DKI Jakarta, responden 100\% memberikan jawaban tidak terlibat dalam pelaksanaan, 
alasannya karena tugas PMKS merupakan tugas Dinas Sosial bukan menjadi tugas unit/instansinya.

Demikian juga dalam hal pembinaan PMKS di Panti Sosial Comal Kabupaten Pemalang Pemprov Jawa Tengah semua (100\%) responden menyatakan tidak terlibat, alasannya karena tugas pembinaan lebih lanjut sebagaimana tahapan pelaksanaan kerjasama (gambar 4) terhadap PMKS yang dikembalikan merupakan tugas Pemerintah Propinsi Jawa Tengah, dan disamping itu anggaran terhadap pembinaan PMKS di Panti Sosial Samekto Karti Comal Pemalang sangat terbatas artinya tidak memadai.

Mengenai tanggapan responden terhadap program penanggulangan PMKS melalui kerjasama antara Pemprov DKI Jakarta dengan Pemprov Jawa Tengah, semua 100\% menyatakan setuju, artinya program ini dianggap dapat membantu Pemprov DKI Jakarta mengatasi masalah sosial khususnya masalah PMKS.

Dari uraian tersebut diatas dapat ditarik kesimpulan bahwa unit/instansi yang dikelompokkan sebagai pendukung program kerjasama antara Pemprov DKI Jakarta dengan Pemprov Jawa Tengah, dilihat dari tertib organisasi dan administratif adalah sudah benar artinya kelompok ini tidak mau melaksanakan tugas yang bukan tupoknya. Ini sering disebut dengan organisasi yang menganut "Role Driven". Namun, bila dilihat dari "Role Mission" bahwa program kerjasama antara Pemerintah Propinsi DKI Jakarta dengan Propinsi Jawa Tengah dalam penanggulangan PMKS merupakan kesepakatan 'kedua Daerah untuk menyelesaikan masalah sosial (PMKS) perlu dirubah, sebab sebagai unsur staf seharusnya tidak perlu berpikiran seperti itu artinya paradigma Role Driven itu diganti menjadi Role Mission. Demikian juga bila dilihat dari pengertian partisipasi dan amanat Pasal 34 UUD 1945, dituntut keterlibatan masyarakat/instansi pemerintah dalam penanganan PMKS (sosial).

\section{Pandangan Dari Sisi Tokoh Masyarakat/Pengurus LSM}

Untuk melengkapi penelitian ini, peneliti meminta pendapat (opini) pengurus Lembaga Swadaya Masyarakat (LSM) atau tokoh masyarakat yang bergerak dibidang PMKS yang berdomisili di Jakarta. Sedang dari Jawa Tengah sebagai responden adalah Kepala Panti Sosial Samekto Karti, jadi jumlah responden sebanyak 6 (enam) orang. Penulis ingin mengetahui bagaimana tanggapan responden terhadap program penanganan PMKS melalui kerjasama antara Pemprov DKI Jakarta dengan 
Pemprov Jawa Tengah . Untuk jelasnya dapat lihat pada gambar dibawah ini.

\section{Gambar 7}

Tanggapan LSM/Tokoh Masyarakat Terhadap Penanganan PMKS Melalui Kerjasama Antara Pemprov DKI Jakarta Dengan Pemprov Jawa Tengah

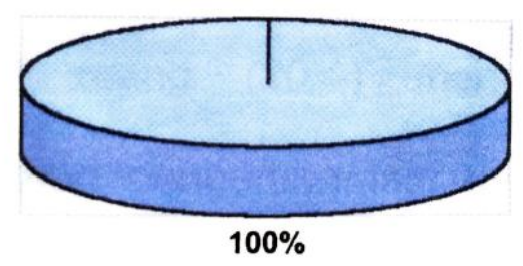

Gambar 7 tersebut memperlihatkan ternyata Tokoh Masyarakat/LSM berpendapat bahwa penanganan PMKS DKI Jakarta dilakukan melalui kerjasama antara PemProV DKI Jakarta dengan Pemprovi Jawa Tengah semuanya setuju ( 100\%). Adapun alasan responden menyatakan setuju program kerjasama tersebut :

- PMKS yang dikembalikan memang berasal dari Jawa Tengah

- Urbanisasi terbesar ke Jakarta adalah Jawa Barat dan Jawa Tengah

- Dengan adanya kerjasama antar Daerah akan memudahkan koordinasi

- Dengan kerjasama penanganan PMKS bisa tepat dan lebih efektif

\section{Gambar 8}

Tanggapan LSM/Tokoh Masyarakat Terhadap Petugas Dinas Sosial

DKI Jakarta Dalam Penanganan PMKS Asal Jawa Tengah

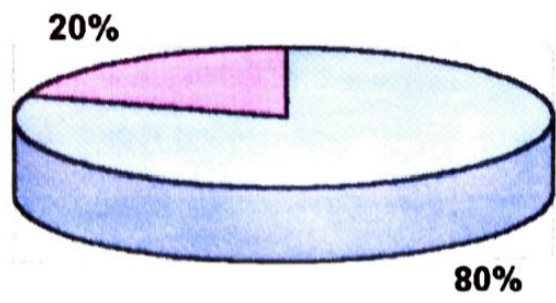


Gambar 8 tersebut memperlihatkan bahwa tanggapan Tokoh Masyarakat/LSM terhadap petugas Dinas Sosial DKI Jakarta dalam penanganan PMKS, sebanyak 4 (empat) orang (80\%) menyatakan Ya artinya penanganan PMKS oleh petugas OKI Jakarta baik, sedangkan sebanyak 1 (satu) orang (20\%) menyatakan tidak setuju cara penanganannya, dengan pengertian lain perlu dibenahi Petugas (SOM) Dinas Sosial DKI Jakarta.

Adapun alasan ketidak setujuan responden dikarenakan :

- Petugas bertugas hanya berdasarkan juklak dan juknis.

- Tidak memperhatikan asal Daerah yang ditangkap di jalanan.

\section{Gambar 9}

\section{Tanggapan LSM/Tokoh Masyarakat Terhadap Petugas Dinas Sosial}

\section{DKI Jakarta Dalam Pembinaan PMKS Asal Jawa Tengah}
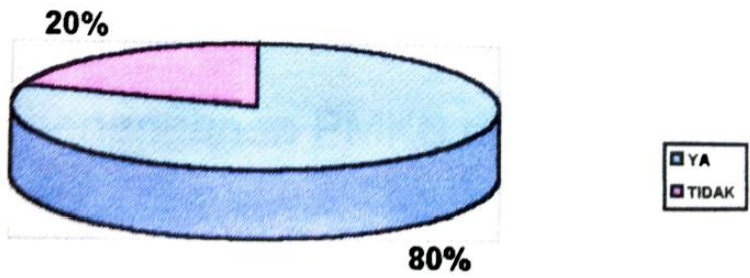

Gambar 9 tersebut memperlihatkan bahwa Tokoh Masyarakat/LSM berpandangan bahwa ternyata petugas Dinas Sosial OKI Jakarta belum optimal melakukan pembinaan terhadap PMKS, ini terlihat dari komentar responden sebanyak 1 (satu) orang.

Adapun alasan ketidak setujuan responden dikarenakan pada waktu pembinaan terhadap PMKS petugas kurang memperhatikan masalah kultur dan budaya antar Daerah di Indonesia yang berbeda, sehingga penanganan PMKSdisama-ratakan.

Gambar 10

Tanggapan LSM/Tokoh Masyarakat Terhadap Partisipasi Masyarakat DKI Jakarta Dalam Penanganan PMKS

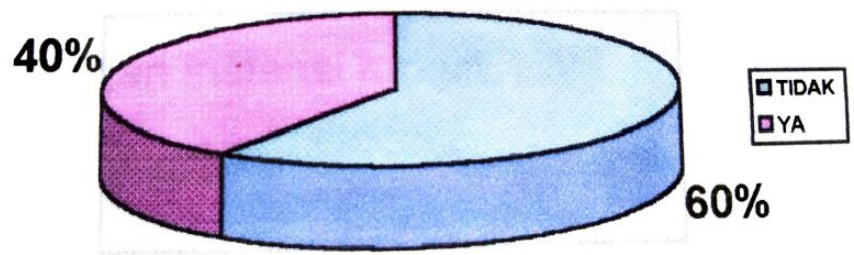


Gambar 10 tersebut memperlihatkan ternyata Tokoh Masyarakat/ LSM berpendapat bahwa masyarakat OKI Jakarta belum optimal berpartisipasi dalam penanganan PMKS.

lni dapat dilihat dari jawaban responden yang menyatakan tidak 3 (tiga) orang (60\%) dan 2 (dua) orang $(40 \%)$ menyatakan Ya, artinya mereka berpartisipasi dalam penanganan PMKS di DKI Jakarta. Adapun alasan responden mengatakan masyarakat Jakarta kurang berpartisipasi dalam penanganan PMKS dikarenakan:

1. Warga Jakarta bersifat individualis

2. Kurang merespon lingkungan sosialnya

3. Kurang peduli dengan PMKS

4. Memberi rangsangan kepada peminta-minta dengan memberi bila diminta oleh peminta.

Saran yang disampaikan oleh responden terhadap program kerjasama antara Pemprov DKI Jakarta dengan Propinsi Jawa Tengah dalam penanggulangan PMKSsebagai berikut :

1. Agar di daerah asal (Jawa Tengah) ditingkatkan lapangan kerja.

2. Agar aparat yang terl ibat dalam penanganan PMKS lebih profesional

3. Agar LSM yang bergerak dibidang PMKS koordinasinya ditingkatkan

4. Agar koordinasi dengan instansi terkait, LSM, Perguruan ditingkatkan.

Efektivitas Penanganan PMKS Melalui Kerjasama Antara PemprovDKI Jakarta Dengan Pemprov Jawa Tengah.

Untuk mengetahui efektivitas keberhasilan penanganan PMKS melafui kerjasama antar Daerah, dari instansi/unit yang termasuk dalam kelompok ini ditanyakan sebagai bahan pembanding dari jawaban kelompok pelaksana. Untuk menjelaskan apakah PMKS yang dibina di Panti Sosial Comal Pemalang, ada yang kembali lagi ke Jakarta, dapat disalurkan menjadi tenaga kerja, kembali ke desa asal menjadi usaha mandiri dan mengikuti program transmigrasi dapat dilihat pada tabel dibawah ini.

\section{Tabel 8}

\section{EFEKTIVITAS PEMBINAAN TERHADAP PMKS DI PANTI SAMEKTO} KARTI, COMAL PEMALANG JAWA TENGAH

\begin{tabular}{|c|c|c|c|c|c|c|c|c|}
\hline No. & $\begin{array}{c}\text { TAHUN } \\
\text { ANGGAR } \\
\text { AN }\end{array}$ & $\begin{array}{c}\text { JUMLAH } \\
\text { PENGIRI } \\
\text { MAN } \\
\text { PMKS }\end{array}$ & $\begin{array}{c}\text { KEMBALI } \\
\text { KAE } \\
\text { MASYRA } \\
\text { KAT }\end{array}$ & $\begin{array}{c}\text { PIND } \\
\text { AH } \\
\text { PANTI }\end{array}$ & $\begin{array}{c}\text { TRANSMIG } \\
\text { RASI }\end{array}$ & $\begin{array}{c}\text { MAND } \\
\text { IRI }\end{array}$ & $\begin{array}{c}\text { DI } \\
\text { PANTI }\end{array}$ & KET \\
\hline 1 & $1997 / 1998$ & 1.259 & 961 & 114 & $55 \mathrm{KK}: 157$ & 27 & -- &
\end{tabular}




\begin{tabular}{|c|c|c|c|c|c|c|c|c|}
2 & $1998 / 1999$ & 740 & 583 & 93 & $13 \mathrm{KK}: 45$ & 18 & 1 & \\
3 & $1999 / 2000$ & 1.335 & 1.176 & 125 & -- & 15 & 19 & \\
\hline & JUMLAH & 3.334 & 2.720 & 332 & $68 \mathrm{KK}: 202$ & 60 & 20 & \\
\hline
\end{tabular}

Sumber : Panti Karya Samekto Karti Comal Pemalang Jawa Tengah, Data Proyek Bantuan dari Pemerintah Propinsi DKI Jakarta, Februari 200

Tabel 8 mernperlihatkan bahwa PMKS yang dikembalikan dari Jakarta ke Daerah asal (Jawa Tengah), ternyata setelah dibina di Panti Karya Samekto Karti, ada yang kembali ke masyarakat 2.720 jiwa (1997 sampai dengan 1999) ' mandiri sebanyak 60 jiwa (1997 s/d 1999), transmigrasi sebanyak 68 KK dan 202 jiwa (1997 s/d 1999), dan juga pindah Panti.

Dari uraian tersebut diatas dapat ditarik kesimpulan, apabila kita menggunakan ukuran efektivitas sebagaimana dikemukakan oleh Paul o. Epstein melalui pengukuran pemberian jasa (measures of services accoumplisment) berarti dalam penanganan PMKS di DKI Jakarta dapat dikatakan bahwa pelayanan jasa yang dilakukan Pemprov DKI Jakarta terhadap PMKS asal Jawa Tengah sudah memadai, artinya mereka yang dikembalikan ke Jawa Tengah jumlah populasi dari tahun ke tahun tumbuh secara signifikan. Ini bisa terjadi karena pelayanan petugas Dinas Sosial Pemprov DKI Jakarta relatif baik. Sedangkan dari sisi Pemprov Jawa Tengah dengan menggunakan pengukuran atas kepuasan dan persepsi pelanggan dan warga (measures of citizen or client satisfaction and perception), Pemerintah Jawa Tengah tidak lagi merasa terbebani dalam penanganan PMKS karena adanya kerjasama dengan Pemprov DKI Jakarta.

\section{A. PEMECAHAN MASALAH}

Sebelum dikemukakan diskripsi pemecahan masalah, maka terlebih dahulu diutarakan masalah yang dihadapi dengan demikian dapat lebih mudah memberikan solusinya. Masalah yang diarakan disini bertitik tolak dari hal-hal sebagai berikut

1. Hubungan Visi, Program, Anggaran dan Pengawasan dalam pelaksanaan program kerjasarna antara Pemprov DKI Jakarta dengan Pemprov Jawa Tengah.

2. Kesesuaian kinerja dengan teori-teori pendukung.

3. Fakta kinerja kerjasama antara Pemprov DKI Jakarta dengan Pemprov Jawa Tengah sebagaimana dikernukakan dalam Bab II.

4. Pernyataan-pernyataan responden yang menyatakan tidak.

\section{Faktor Visi}

Apabila diperhatikan uraian tentang Visi, yang dianalisa dari sisi penentu kebijakan, pelaksana, pendukung dan tokoh rnasyarakat, dalam program penanganan PMKS melalui kerjasama antara Pemprov DKI Jakarta dengan Pemprov Jawa Tengah, terdapat 1 (satu) orang menyatakan Visi tidak dapat dijadikan sebagai solusi dan 1 (satu) orang menyatakan Visi tidak mencapai sasaran/tujuan. 
Demikian juga dilihat dari sisi pelaksana program, 2 (dua) orang menyatakan bahwa Visi tidak dapat dijadikan solusi dan menyatakan Visi tidak menjamin sasaran/tujuan tercapai.

Angka-angka yang mengatakan "Tidak" tersebut bila dibandingkan dengan yang setuju, sebenarnya bisa dikatakan kurang signifikan artinya bahwa visi memang diperlukan dalam pelaksanaan kerjasama antar Daerah.

Apabila disajikan secara sistematis peran Visi yang diharapkan dalam pelaksanaan kerjasama antar Daerah, pernyataan responden sekaligus menjadi masalah yang dihadapi dan solusi pemecahannya, maka nampak dalam tabel sebagai berikut.

\section{Tabel 9}

\section{PERAN VISI DALAM PELAKSANAAN KERJASAMA ANTAR DAERAH}

\begin{tabular}{|c|c|c|}
\hline $\begin{array}{l}\text { PERAN VISI } \\
\text { SEBAGAI }\end{array}$ & $\begin{array}{l}\text { PERNYATAAN RESPONDEN YANG } \\
\text { SEKALIGUS NIASALAH } \\
\end{array}$ & SOLUSIXPEMECAHAN \\
\hline 1. Solusi & $\begin{array}{l}\text { 1. Tidak adanya tindak lanjut dari } \\
\text { Pemerintah Propinsi Jawa Tengah } \\
\text { terhadap PMKS yang } \\
\text { dikembalikan. } \\
\text { 2. Visinya terlalu konsepsional. } \\
\text { 3. Tidak terlibat dalam merumuskan } \\
\text { visi. } \\
\text { 4. Visinya kurang operasional. }\end{array}$ & $\begin{array}{l}\text { 1. Perlu } \text { ditingkatkan } \\
\text { koordinasi antar unit/ } \\
\text { instansi yang terkait } \\
\text { dalam penanganan } \\
\text { PMKS. } \\
\text { 2. Perlu disosialisasikan } \\
\text { visinya dan dibuatkan } \\
\text { strateginya. }\end{array}$ \\
\hline 2. Sasaran/Tujuan & $\begin{array}{l}\text { 1. Belum teruji tingkat keberhasilan- } \\
\text { nya } \\
\text { 2. Apakah PMKS yang telah dibina } \\
\text { lebih baik, tingkat kehidupannya } \\
\text { dibandingkan pada waktu menjadi } \\
\text { PMKS di Jakarta. } \\
\text { 3. Apakah PMKS yang telah dibina } \\
\text { dan mendapat pekerjaan sudah } \\
\text { yang sesuai dan layak. } \\
\text { 4. Di Jakarta masih banyak PMKS. }\end{array}$ & $\begin{array}{l}\text { 1. Perlu pembinaan lebih } \\
\text { lanjut terhadap PMKS } \\
\text { yang kembali ke tengah } \\
\text { masyarakat. } \\
\text { 2. Perlu dimonitoring PMKS } \\
\text { yang kembali ke tengah } \\
\text { masyarakat. } \\
\text { 3. Perlu ada kerjasama } \\
\text { antara Pemerintah } \\
\text { Propinsi Jawa Tengah } \\
\text { dengan perusahaan } \\
\text { dimana PMKS disalurkan } \\
\text { bekerja. } \\
\text { 4. Perlu di monitoring dan } \\
\text { evaluasi (MONEV) } \\
\text { penanganan PMKS. }\end{array}$ \\
\hline
\end{tabular}

\section{Faktor Program}

Apabila diperhatikan uraian tentang program yang dianalisa dari sisi penentu kebijakan, pelaksana, pendukung dan tokoh masyarkat, dalam program penanganan PMKS melalui kerjasama antara Pemprov DKI Jakarta dengan Pemprov Jawa Tengah, terdapat sebanyak 4 (empat) orang yang menyatakan bahwa program tidak didahului dengan suatu studi kelayakan; 2 (dua) orang menyatakan bahwa program penanggulangan PMKS bukan rnerupakan suatu kebutuhan, sedang $100 \%$ menyatakan bahwa sasaran tujuan penanganan PMKStercapai. 
Dikatakan tercapai sasaran/tujuan karena Pemprov DKI Jakarta berhasil memulangkan PMKS asal Jawa Tengah ke Panti Sosial Samekto Karti Comal pada tahun 1997 sebanyak 1.259 orang; tahun 1998 sebanyak 740 orang dan pada tahun 1999 sebanyak 1. 335 orang. Disamping itu keberhasilan dalam penanganan PMKS paling tidak bagi Pemprov DKI Jakarta mengurangi beban Daerah.

Jawaban yang menyatakan tidak tersebut bila disajikan secara sistematis peran program dalam pelaksanaan kerjasama antar Daerah, pernyataan responden sekaligus menjadi masalah yang dihadapi dan solusi pemecahannya, maka nampak dalam tabel sebagai berikut :

\section{Tabel 10}

\section{PERAN PROGRAM DALAM PELAKSANAAN KERJASAMA ANTAR DAERAH}

\begin{tabular}{|c|c|c|}
\hline PEORAN & $\begin{array}{l}\text { PERWYATAAN RESPONDEN YANG } \\
\text { SEKALIGUS MASALAH }\end{array}$ & SOLUSWPENECAHAN \\
\hline 1. Studi kelayakan & 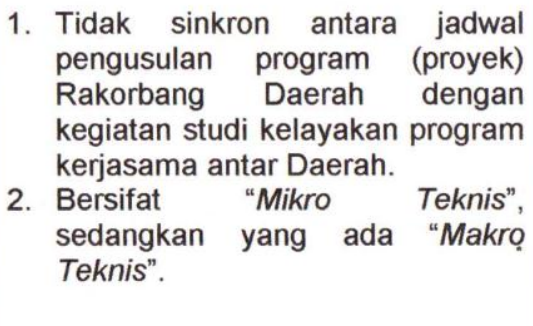 & $\begin{array}{l}\text { 1. Perlu dibentuk Pokja } \\
\text { Daerah yang khusus } \\
\text { meneliti kebutuhan } \\
\text { Daerah yang layak untuk } \\
\text { dikerjasamakan. } \\
\text { 2. Perlu dipertegas bahwa } \\
\text { program kerjasama antar } \\
\text { Daerah harus dilakukan } \\
\text { studi kelayakan. }\end{array}$ \\
\hline 2. Kebutuhan & Bukan merupakan prioritas Daerah. & $\begin{array}{l}\text { Perlu disepakati bahwa } \\
\text { program yang akan } \\
\text { dikerjasamakan haruslah } \\
\text { merupakan kebutuhan kedua } \\
\text { Daerah. }\end{array}$ \\
\hline
\end{tabular}

\section{Faktor Anggaran}

Dari uraian sebelumnya tentang anggaran bila dianalisa dari sisi penentu kebijakan, pelaksana dan pendukung program penanggulangan PMKS melalui kerjasama antara Pemprov DKI Jakarta dengan Pemprov Jawa Tengah, terdapat 1 (satu) orang yang menyatakan bahwa Daerah tidak konsisten mendukung, dan 1 (satu) orang menyatakan bahwa Anggaran yang dialokasikan oleh Daerah tidak mencapai sasaran/tujuan penanganan PMKS melalui kerjasama antara Pemprov DKI Jakarta dengan Pemprov Jawa Tengah.

Hasil analisa tersebut bila disajikan secara sistematis peran Anggaran yang diharapkan dalam pelaksanaan kerjasama antar Daerah, pernyataan responden yang sekaligus menjadi masalah yang dihadapi dan solusi pemecahannya, maka nampak dalam tabel berikut. 


\section{Tabel 11}

\section{PERAN ANGGARAN DALAM PELAKSANAAN KERJASAMA ANTAR DAERAH}

\begin{tabular}{|c|c|c|}
\hline $\begin{array}{l}\text { PEERAN } \\
\text { ANGGARAN } \\
\end{array}$ & $\begin{array}{l}\text { PERWYATAAN RESPONDEN YANG } \\
\text { SEKALIGUS MASALAH } \\
\end{array}$ & SOLUSUPEMECAHAN \\
\hline 1. Konsistensi & $\begin{array}{l}\text { Bagi Pemerintah Propinsi Jawa } \\
\text { Tengah masalah penanganan PMKS } \\
\text { bukan merupakan prioritas, berbeda } \\
\text { dengan Pemerintah Propinsi DKI } \\
\text { Jakarta. }\end{array}$ & $\begin{array}{l}\text { Perlu disamakan persepsi } \\
\text { tentang masalah PMKS, } \\
\text { artinya PMKS di perkotaan } \\
\text { tidak dapat diselesaikan } \\
\text { secara single ended. }\end{array}$ \\
\hline 2. Sasaran/Tujuan & $\begin{array}{l}\text { Walaupun PMKS asal Jawa Tengah } \\
\text { telah dikembalikan/dipulangkan ke } \\
\text { Daerah asalnya, namun PMKS masih } \\
\text { banyak berkeliaran di Jakarta atau } \\
\text { datang lagi ke Jakarta. }\end{array}$ & $\begin{array}{l}\text { Perlu ditingkatkan anggaran } \\
\text { untuk operasi penertiban } \\
\text { dan penyuluhan PMKS. }\end{array}$ \\
\hline
\end{tabular}

\section{Faktor Pengawasan}

Hasil analisa faktor Pengawasan dengan penentu kebijakan, pelaksana, pendukung program penanganan PMKS melalui kerjasama antara Pemprov DKI Jakarta dengan Pemprov Jawa Tengah, terdapat 1 (satu) orang menyatakan bahwa Pengawasan tidak diperlukan dalam program penanganan PMKS, dan 1 (satu) orang menyatakan bahwa program penanganan PMKS melalui kerjasama antara Pemprov DKI Jakarta dengan Pemprov Jawa Tengah tidak perlu di evaluasi, sedangkan 2 (dua) orang menyatakan bahwa kegiatan penanganan PMKS melalui kerjasama antar Daerah sasaran/tujuannya belum tercapai.

Untuk lebih jelasnya hasil analisa tersebut diatas disajikan secara sistematisperan Pengawasan yang diharapkan dalam pelaksanaan kerjasama antar Daerah, pernyataan responden yang sekaligus menjadi masalah yang dihadapi dan solusi pemecahannya, akan terlihat dalam tabel sebagai berikut : 
Tabel 12

PERAN PENGAWASAN DALAM PELAKSANAAN KERJASAMA ANTAR DAERAH

\begin{tabular}{|l|l|l|}
\hline 1. Perlu Pengawasan & $\begin{array}{l}\text { Belum adanya Prosedur Tetap } \\
\text { (Protap) Pengawasan kerjasama } \\
\text { antar Daerah, sehingga bila } \\
\text { dilaksanakan pengawasan ber- } \\
\text { dasarkan fungsi-fungsi } \\
\text { manajemen tidak efektif. }\end{array}$ & $\begin{array}{l}\text { Perlu ditetapkan satu } \\
\text { prosedur dan mekanisme } \\
\text { pengawasan tentang } \\
\text { pelaksanaan/kegiatan/proye } \\
\text { k kerjasama antar Daerah. }\end{array}$ \\
2. Perlu Evaluasi & $\begin{array}{l}\text { Tidak jelasnya tahapan dan } \\
\text { aspek-aspek yang akan di } \\
\text { evaluasi. }\end{array}$ & $\begin{array}{l}\text { Perlu disepakati terlebih } \\
\text { dahulu apa yang akan di } \\
\text { evaluasi artinya apakah } \\
\text { programnya, hasilnya atau } \\
\text { pelaksanaannya yang akan } \\
\text { di evaluasi. }\end{array}$ \\
3. Sasaran/Tujuan & $\begin{array}{l}\text { PMKS yang sudah dibina di Panti } \\
\text { Sosial Samekto Karti dan sudah } \\
\text { dimasyarakatkan tidak di monitor. }\end{array}$ & $\begin{array}{l}\text { Perlu pembinaan lebih lanjut } \\
\text { terhadap PMKS hasil binaan } \\
\text { oleh Pemerintah Propinsi } \\
\text { Jawa Tengah. }\end{array}$ \\
\hline
\end{tabular}

\section{Partisipasi Unit/Instansi Pemerintah Daerah}

Signifikan hubungan antara partisipasi instansi/unit dengan program penangann PMKS melalui kerjasama antara Pemprov DKI Jakarta dengan Pemprov Jawa Tengah, terdapat 5 (lima) orang yang menyatakan bahwa instansi/unit Pemda tidak terlibat dalam persiapan penanganan PMKS, sedangkan semua responden (100\%) menyatakan tidak terlibat dalam pelaksanaan maupun pembinaan penanganan PMKS.

Hal ini nampak dalam beberapa indikasi sesuai dengan pernyataan responden yang sekaligus dapat merupakan masalah yang dihadapi dan solusi pemecahannya akan terlihat dalam tabel berikut ini. 
Tabel 13

PERAN PARTISIPASI/KETERLIBATAN INSTANSI/UNIT DALAM PELAKSANAAN KERJASAMA ANTAR DAERAH

\begin{tabular}{|c|c|c|}
\hline $\begin{array}{l}\text { PERAN } \\
\text { PARTISIPASI } \\
\end{array}$ & $\begin{array}{l}\text { PERTIVATAANU RESPONDENI YG } \\
\text { SEKALIGUS MASALAH } \\
\end{array}$ & SOLUSIIPEMECAHANI \\
\hline 1. Persiapan & $\begin{array}{l}\text { Tidak terlibat karena bukan } \\
\text { merupakan tupoknya menangani } \\
\text { PMKS. }\end{array}$ & $\begin{array}{l}\text { Perlu ditingkatkan sosialisasi kepada } \\
\text { pejabat tentang arti penting nya } \\
\text { penanganan PMKS oleh semua } \\
\text { pihak/instansi yang terkait. }\end{array}$ \\
\hline 2. Pelaksanaan & $\begin{array}{l}\text { Terdapat perbedaan persepsi dari } \\
\text { instansi terkait tentang arti terlibat } \\
\text { dalam pelaksanaan. Ada yang } \\
\text { berpendapat bahwa terlibat } \\
\text { maksudnya dalam arti fisik. }\end{array}$ & $\begin{array}{l}\text { 1. Perlu disosialisasikan tugas dan } \\
\text { fungsi unit/instansi yang terkait } \\
\text { dalam penanganan PMKS melalui } \\
\text { kerjasama antar Daerah. } \\
\text { 2. Perlu ditingkatkan koordinasi di } \\
\text { Daerah masing-masing dalam } \\
\text { keterlibatan penanganan PMKS } \\
\text { melalui kerjasama antar Daerah. }\end{array}$ \\
\hline 3. Pembinaan & $\begin{array}{l}\text { 1. Tugas pembinaan lebih lanjut } \\
\text { merupakan tugas Pemerintah } \\
\text { Propinsi Jawa Tengah. } \\
\text { 2. Anggaran yang disediakan oleh } \\
\text { Pemerintah Propinsi Jawa } \\
\text { Tengah untuk pembinaan PMKS } \\
\text { di Comal terbatas. }\end{array}$ & $\begin{array}{l}\text { 1. Perlu ditingkatkan koordinasi antara } \\
\text { pejabat yang terkait dalam } \\
\text { pembinaan PMKS di Jawa Tengah. } \\
\text { 2. Perlu disamakan persepsi dengan } \\
\text { instansi yang terkait dengan } \\
\text { anggaran, bahwa pembinaan PMKS } \\
\text { perlu didukung anggaran. }\end{array}$ \\
\hline
\end{tabular}

\section{E. Kesimpulan}

Berdasarkan analisis yang telah dikemukakan pada bagian - bagian diatas, telah terjawab bahwa Visi kerjasama antar daerah sebagai arah/ pedoman untuk melaksanakan penaganan PMKS, Konsistensi daerah dan dukungan terhadap anggaran penanganan PMKSmelalui kerjasama antar daerah dan Pengawasan terhadap pelaksanaan program penanganan PMKS telah dilakukan melaluikerjasama antar daerah.

1. KeduaDaerah merasakan manfaat dari kerjasama antara Pemerintah Prov.DKI Jakarta dengan Prov.Jawa Tengah dalam penanganan PMKS.

Sehingga secara umum pelaksanaan penanganan PMKS melalui kerjasama antara Pemprov DKI Jakarta dengan Pemprov.Jawa Tengah sudah berjalan. Berjalannya kerjasama ini ditunjukkan oleh hampir seluruh variable maupun indicator yang digunakan, yaitu VISI, Program, Anggaran dan Pengawasan serta Partisipasi instansi / unit dan partisipasi masyarakat menunjukkan positif .

2. Dengan kinerja sebagaimana yang diuraikan diatas, pelaksanaan kerjasama antar daerah dipandang memiki kelebihan atau daya Tarik dalam hal membantu menyelesaikan masalah sosial (PMKS) yang dihadapi daerah, sehingga umumnya daerah lain berminat untuk melaksanakan kerjasama dengan PemprovDKI Jakarta. 
3. Penanganan PMKS secara sepihak (single handed) dengan tidak memperhatikan factor-faktor lain seperti : ekonomi, lapangan kerja, akan kurang berhasil pelaksanaan kerjasamanya, artinya penanganan PMKS akan tidak efektif bila tidak diselesaikan secara konprehensif (hulu-hilir) .

4. Dari empat sub variable ( VISI, Program, Anggaran dan Pengawasan ), hanya sub variable visi yang signifikan dalam pelaksanaan penanganan PMKS melalui kerjasama antar Daerah artinya pejabat penentu kebijakan, pelaksana, pendukung/partisipan dan tokoh masyarakat, menganggap bila pelaksanaan kerjasama antar Daerah akan berhasil bila ada Visi yang jelas Adapun variable yang lain (Progaram, Anggaran dan Pengawasan ), mempunyai peran dalam pelaksanaan penanganan PMKS melalui kerjasama anatar Daerah, hanya tidak sekuat variable visi, artinya ketiga variable tersebut diperlukan dan semakin baik bila dilaksanakan secara konsisten .

5. Kondisi external, yaitu respon yang diberikan oleh masyarakat/tokoh masyarakat maupun pengurus LSM terhadap peleksanaan kerjasama antar Daerah adalah positif. Mereka pada prinsipnya menyetujui untuk penanganan PMKS di DKI Jakarta dilakukan melalui kerjasama antar DaerahSecara umum manfaat kerjasama antara Pemprov DKI Jakarta dengan Pemprov Jawa Tengah, dapat dilihat dari even-even Nasional maupun Internasional artinya dengan adanya even tersebut di Jakarta masalah PMKS dapat dipulangkan ke Daerah asal, sehingga tidak terlihat kesemrawutan kota Jakarta yang dipenuhi oleh Gepeng, WTS dll .

\section{F. Saran}

Untuk peningkatan kinerja pelaksanaan KAD Pemprov DKI Jakarta dengan Pemprov Jawa Tengah, Agar Visi dapat berfungsi sebagai solusi maka;

1. Perlu Koordinator antar unit/instansi yang terkait dalam penanganan PMKS dan perlu di Sosialisasikanvisinya kepada pejabat pimpinan unit dan Visinya agar dibuat strateginya.

2. Agar Visi dapat berfungsi sebagai sasaran/tujuan perlu dilakukan pembinaan lebih lanjut dan MonitoringterhadapPMKS yang kembali ketengah masyarakat.

3. Agar variable Program dapat berfungsi sebagai study kelayakan, perluDibentuk Pokja Daerah Yang khusus meneliti kebutuhan Daerah yang layak dikerjasamakan, Penegasan bahwa program KAD harus terlebih dahulu dilakukan study kelayakan/kajian.

4. Agar variable Program sebagai kebutuhan, perlu dilakukan Kesepakatan bahwa program yang akan dikerjasamakan haruslah merupakan kebutuhan kedua daerah.

5. Agar variable Anggaran sebagai konsistensi, perlu dilakukan: Penyamaan persepsi tentang masalah PMKS, artinya PMKS diperkotaan tidak dapat diselesaikan secara single handed, demikian juga agar variable pengawasan efektif perlu dilakukan: Penetapan satu prosedur dan mekanisme pengawasan tentang pelaksanaan / kegiatan / proyek KAD, dan perlu kesepakatan terlebih dahulu apa yang akan di evaluasi artinya apakah 
proramnya, hasilnya atau pelaksanaannya yang akan di evaluasi.Agar variable Partisipasi Masyarakat efektif dalam kegiatan KAD, perlu dilakukanPensosialisasian tugas dan fungsi unit/instansi yang terkait dalam penanganan PMKS melalui KAD.

\section{DAFTAR PUSTAKA}

Bennis, Warren G. 1990. Merencanakan Perubahan. Alih BahasaWilhelmut W. Bakowatun. Jakarta : Intermedia.

Bennis \& Warren Michael Mische. 1991. Organisasi Abad 21. Alih BahasaIrma Adriani Rahmayanti. Jakarta : Teruna Grafika .

Creech, Bill. 1996. Lima Pilar Manaje5men Mutu Terpadu. Jakarta: Banarupa Aksara. Edisi Pertama. Terjemahan.

Covey, Stepen R . 1997 . The 7 Habits Of Highly Effektiv People, Alih Bahasa Budijanto . Jakarta : Binarupa Aksara .

Carli Usman Cushwy, Barry . 1994 . Human Resource Management, Management Sumber Daya Manusia . Jakarta : Elx Media, Koputerindo Terjemahan .

Danim Sudarwan . 1997 . Pengantar Studi PenelitiaN kEBIJAKAN . Jakarta : Bumi Aksara . Edisi ke-satu, Cetakan ke - satu.

Dunn, W.N. 1988 , Analisa Kebujaksanaan Publik , Terjemahan Oleh Muhadjir Darwin . Yogjakarta : Hanindita .

Dye , T.R . 1981 . Understanding Publik Policy . Fourth Edition . New York : Pretice Hall , Indonesia . Fourth Edition .

Gibson, James L . Cs . 1985 . Organization, Behavior , Structure , Processes, Business Publications . Inc , Plans Texas, Fifth Edition .

Huseini , Martani . 1989 . Perencanaan Strategik Dalam Organisasi . Jakarta : Pusat Antar Universitas Ilmu-Ilmu Sosial UI .

James, Patricia Cs . 1990 . Misi dan VISI 50 Perusahaan Terkenal di Dunia . Batam : Interaksi .

K, Azhar . 1993 . Pengukuran Efektivitas Dalam Organisasi . Jakarta : Lembaga Penerbitan Fakultas Ekonomi UI .

............ 1995 . Teori Pembuatan Keputusan . Jakarta : Lembaga Penerbitan Fakultas Ekonomi UI .

Jones , Patricia \& Larry Khaner . 1991 . MISI dan VISI , 50 Perusahaan Terkenal Di Dunia . Alih Bahasa Anton Adi Wiyoto .

Kotter, John P . 1997 . Leading Change, Alih Bahasa Joseph Bambang MS . Jakarta : PT.Gramedia .

Kritiadi , J.B. 1994 . Administrasi/Manajemen Pembangunan. Jakarta : Lembaga Administrasi Negara .

1997 . Dimensi Praktis Manajemen Pembangunan di Indonesia . Jakarta :

STIA LAN . Cetakan ke-1

Logodeff . 1993 .A Guide To Organizing Mat . Falst Tracking Local Government Capability Building , Manila Logodef.

Lindblom , Ce.e . 1986 . Proses Penetapan Kebijaksanaan . Terjemahan Oleh Syamsudin . Jakarta : Erlangga . Edisi ke-2 . 
Volume 8, Nomor 1, Januari 2019

Lubis , H \& M . Huseini . 1987 . Teori Organisasi Suatu Pendekatan Makro . Jakarta : PAU - IS -UI . 